Universidade de Brasília - UnB

Faculdade de Direito

\title{
GREVE NO SERVIÇO PÚBLICO: \\ UMA CRÍTICA DEONTOLÓGICA À DECISÃO DO STF NO MANDADO DE \\ INJUNÇÃO no 712
}

CÁSSIA CAROLINE CANDIDA CASTRO

BRASÍLIA 


\title{
Universidade de Brasília - UnB \\ Faculdade de Direito
}

\author{
CÁSSIA CAROLINE CANDIDA CASTRO
}

\section{GREVE NO SERVIÇO PÚBLICO:}

UMA CRÍTICA DEONTOLÓGICA À DECISÃO DO STF NO MANDADO DE INJUNÇÃO no 712

\author{
Monografia apresentada como \\ requisito parcial à obtenção do título \\ de bacharel em Direito pela Faculdade \\ de Direito da Universidade de Brasília - \\ UnB. \\ Orientador: Prof. Dr. Paulo Henrique \\ Blair de Oliveira
}




\section{GREVE NO SERVIÇO PÚBLICO: \\ UMA CRÍTICA DEONTOLÓGICA À DECISÃO DO STF NO MANDADO DE INJUNÇÃO no 712}

Monografia aprovada como requisito parcial à obtenção do título de bacharel em Direito pela Faculdade de Direito da Universidade de Brasília - UnB, pela banca examinadora composta por:

Prof. Dr. Paulo Henrique Blair de Oliveira (Orientador)

Universidade de Brasília - UnB

Prof. Dr. Juliano Zaiden Benvindo

Universidade de Brasília - UnB

Prof. Dr. Argemiro Cardoso Moreira Martins

Universidade de Brasília - UnB

Prof. Guilherme Scotti

Universidade de Brasília - UnB 


\section{AGRADECIMENTOS}

A Deus, por todas as bênçãos e por iluminar o meu caminho.

Aos meus queridos pais, Sirlania e Ricardo, por tudo que me ensinaram, pelo carinho e confiança incondicionais e pelo incentivo constante a buscar a concretização dos meus sonhos. Ao meu irmão Luiz Fernando, pelos sorrisos fáceis que tanto me alegram. $E$ a todos os meus familiares, sem exceção, pelo apoio fundamental e pela torcida pelo meu sucesso.

Ao Carlos Henrique, pela companhia sempre presente e pelo amor e dedicação que tornam a caminhada mais simples e alegre. A Hellen, pela amizade e cumplicidade, por sua capacidade de ouvir e de compreender.

Aos meus amigos e colegas de graduação, por compartilharem anseios e aprendizados e por tornarem esses cinco anos tão mais divertidos. Em especial, a Fernanda Kawano, Priscila Koshino, João de Deus, Maria Lemus, Guilherme Sivieri, Uiára Cerqueira, Nilson Dias e Fernanda Moura por dividirem momentos inesquecíveis.

Ao professor Paulo Blair, pela orientação excepcional, pela atenção e entusiasmo com que me guiou e pelos ensinamentos que vão muito além da elaboração deste trabalho. Muito obrigada por despertar angústias e emoções que tornaram a pesquisa tão gratificante. Agradeço pelo privilégio da orientação e pelo exemplo de dedicação profissional que é peculiar daqueles que são apaixonados pelo que fazem.

À Universidade de Brasília e ao corpo docente da Faculdade de Direito, pela excelência do ensino e pelo amadurecimento intelectual proporcionado. É com alegria e satisfação que concluo a graduação e abro caminho para novos desafios. 


\section{RESUMO}

Desde o julgamento do MI no 20, em 1994, o STF tem considerado o direito de greve dos servidores públicos como norma de eficácia limitada, condicionando o exercício de tal direito à edição da norma regulamentadora prevista pelo art. 37, VII, da Constituição. Desde então, o tribunal tem se limitado a declarar a mora do legislador e a notificá-lo para que a omissão seja suprida, tornando o mandado de injunção um instrumento inócuo. Em 2007, porém, por ocasião do julgamento do $\mathrm{Ml}$ no 712 , o STF reformula a compreensão do próprio tribunal em relação ao mandado de injunção. O objetivo do presente trabalho é analisar como e por que houve essa reformulação e o que ela significa. Busca-se também analisar como se dá a leitura do direito de greve pela Corte Constitucional e a eficácia de tal direito dos servidores públicos no contexto brasileiro, tendo como objeto de análise a decisão proferida no Mandado de Injunção no 712. Para tal investigação, faremos a contraposição entre a axiologia e a deontologia jurídica para notar diferentes modos de conformação da Constituição com objetivo de compreender como o STF decidiu o MI nำ712. Utilizaremos, para tanto, as teorias do direito de Robert Alexy e Ronald Dworkin. O problema de pesquisa do presente estudo é, portanto, compreender se e em que medida o caso do direito de greve dos servidores públicos revela a assunção efetiva, pelo STF, de uma leitura deontológica da Constituição.

PALAVRAS-CHAVE: direito de greve; servidores públicos; direitos fundamentais; mandado de injunção; Supremo Tribunal Federal; axiologia jurídica; deontologia jurídica. 


\section{SUMÁRIO}

1. INTRODUÇÃO

2. AXIOLOGIA JURídicA: ESTRUTURA DA TEORIA dO DIREITO DE ROBERT AlEXY..10

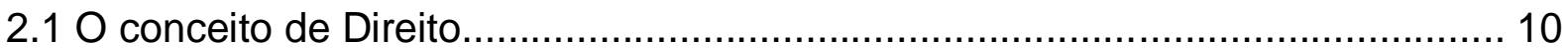

2.2 Teoria da argumentação jurídica............................................................. 13

2.3 A ponderação

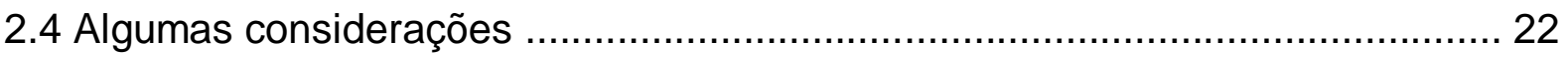

3. DeOntologia juRÍdica: estrutura dA teORIA do DiREITO de RONALD

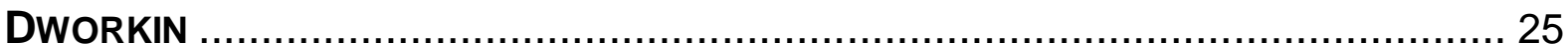

3.1 Uma teoria geral do direito e as críticas ao positivismo jurídico ........................ 25

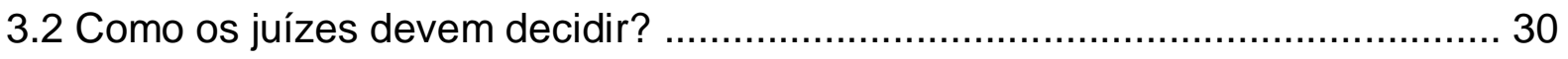

$3.3 \mathrm{O}$ direito como integridade …................................................................. 33

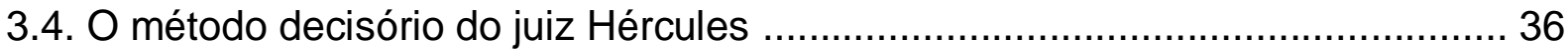

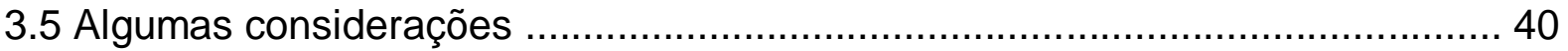

4. ANÁLISE DE CASO: O DIREITO DE GREVE DOS SERVIDORES PÚBLICOS ............. 43

$4.1 \mathrm{O}$ direito de greve como direito à violência ................................................... 43

4.2 O direito de greve no ordenamento jurídico brasileiro ...................................... 45

$4.3 \mathrm{O}$ direito de greve dos servidores públicos e sua conformação pelo STF ......... 47

4.4 Reflexos e consequências da decisão proferida no MI № 712 .......................... 56

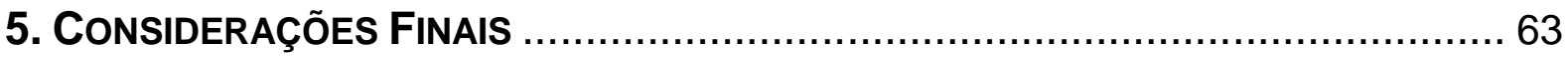

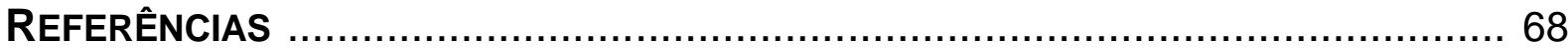




\section{INTRODUÇÃO}

O direito de greve é um direito capaz de incomodar, de inquietar. Durante os cinco anos de graduação na Universidade de Brasília não foram raros os momentos em que nos deparamos com greves de servidores públicos, ora de professores ora de funcionários, que interrompiam as aulas e deixavam a universidade em clima de tensão. Também não foram raros os momentos em que presenciamos discursos de indignação afirmando a "injustiça" do exercício de tal direito, que prejudicava inúmeros alunos, projetos de pesquisa e todo o desenvolvimento normal das atividades do semestre. Esse tipo de discurso era possível de ser encontrado entre os próprios estudantes, bem como em diversos debates públicos vinculados na imprensa.

De fato, as greves na universidade incomodavam. Foi, então, que surgiu a inquietação em torno do direito de greve e de sua natureza. Em janeiro de 2010, ao cursar a disciplina Direito Coletivo do Trabalho, uma afirmação do professor Ricardo Lourenço me chamou atenção: "o direito de greve é o direito de incomodar, é o direito à violência". A força das palavras utilizadas não me deixou dúvidas quanto à fascinação e ao desejo de investigação pelo tema.

O direito de greve dos servidores públicos, apesar de ter status de direito fundamental assegurado pela Constituição, ainda não foi regulamentado no âmbito infraconstitucional, conforme previsto pelo art. 37, VII, o que faz suscitar uma série de debates sobre a possibilidade de seu exercício. Nesse contexto, foram impetrados mandados de injunção perante o STF com o objetivo de viabilizar o exercício de tal direito.

A jurisprudência que predominou no STF, desde 1994, quando do julgamento do $\mathrm{MI} \mathrm{n}^{\circ}$ 20, até 2007, negava a auto-aplicabilidade do art. 37, VII, e condicionava o exercício do direito de greve dos servidores públicos à edição da norma regulamentadora, pois considerava tal direito como norma de eficácia limitada. O STF restringiu-se, portanto, a declarar a mora do legislador e notificá-lo para que a omissão fosse suprida, tornando o mandado de injunção um instrumento inócuo.

A decisão proferida no Mandado de Injunção oㅜ 712, em 2007, permitiu uma série de mudanças a respeito da compreensão do próprio tribunal em torno do 
mandado de injunção, além de discutir e apresentar a concepção do direito de greve pela Corte Constitucional.

O objetivo do presente trabalho é, portanto, analisar como e por que houve uma mudança de compreensão em torno do mandado de injunção e o que ela significa. Busca-se também analisar como se dá a leitura do direito de greve pela Corte Constitucional e a eficácia de tal direito dos servidores públicos no contexto brasileiro, tendo como objeto de análise a decisão proferida no Mandado de Injunção no 712 .

Para efetuar essa investigação, faremos a contraposição entre as correntes filosóficas da axiologia e deontologia jurídica para compreender diferentes formas de decisão judicial e diferentes modos de compreensão da Constituição Federal com o objetivo de notar a qual delas o STF se aproxima ao decidir o MI no 712.

A axiologia jurídica será apresentada com fundamento na teoria do direito de Robert Alexy, um de seus mais influentes representantes. Alexy apresenta a teoria da argumentação jurídica e a ponderação como métodos racionais para garantir que decisões judiciais sejam justas. Segundo ele, princípios são passíveis de colisão e a solução será apresentada pela ponderação dos mesmos, que será feita pelo juiz do caso, a partir de julgamentos de valor. Uma leitura axiológica da Constituição revela-se, portanto, como uma leitura valorativa, que identifica a argumentação jurídica com a argumentação moral.

Uma leitura deontológica, em contraposição, sugere que a Constituição deve ser lida como norma, devendo ser reconhecida em sua força vinculante. Para a compreensão dessa corrente filosófica, utilizaremos como fundamento a teoria do direito de Ronald Dworkin. Segundo ele, o sistema de normas e direitos fundamentais deve ser compreendido como sistema contramajoritário, que garante que indivíduos tenham direitos contra o próprio Estado. Dworkin afirma também que questões jurídicas devem ser decididas com argumentos de princípio e não com argumentos de política, já que os últimos são, em essência, valorativos e majoritários.

Dworkin entende o direito como integridade e, portanto, compreende o sistema de normas e princípios constitucionais como um sistema único e coerente de justiça e equidade. Assim, ele defende a integridade como chave para a melhor 
interpretação das práticas jurídicas e, principalmente do modo como os juízes devem decidir casos difíceis.

Após a investigação e compreensão dessas correntes filosóficas, passaremos à análise do $\mathrm{MI}$ n 712 . O problema de pesquisa do presente estudo é, portanto, compreender se o caso do direito de greve dos servidores públicos revela a assunção efetiva, pelo STF, de uma leitura deontológica da Constituição. Busca-se encontrar os fundamentos e objetivos da mudança da jurisprudência em relação ao mandado de injunção. Ao mesmo tempo, visa-se compreender também qual leitura apresenta o Estado e a Corte Constitucional do direito de greve dos servidores públicos. 


\section{AXIOLOGIA JURídicA: estrutuRA dA TEORIA DO DIREITO DE ROBERT ALEXY}

\subsection{0 conceito de Direito}

Em entrevista a Manuel Atienza, Alexy é indagado sobre quais seriam os problemas centrais de seu trabalho filosófico e se haveriam respostas aos mesmos. Ele afirma que o centro de sua teoria é o problema da conexão entre Direito e razão, de modo que intenta responder o que é Direito, o que é razão e no que consiste a conexão entre ambos.

A resposta à primeira pergunta é complexa. Para Alexy, Direito consiste em três elementos: (i) a legalidade em conformidade com o ordenamento, (ii) a eficácia social e (iii) a correção quanto ao conteúdo ou a pretensão de correção. Segundo ele, o primeiro elemento representa a institucionalidade do Direito, o segundo sua facticidade e o terceiro sua moralidade. Entre esses três elementos há muitas relações necessárias:

La eficacia sin legalidad supone inmutabilidad, la legalidad sin eficacia carece de fuerza, y ambas conjuntamente no es todavía Derecho si no se plantea al menos una pretensión de corrección. ${ }^{1}$

A pretensão de correção é, novamente, um conceito complexo. Significa que o Direito deve incluir, necessariamente, uma pretensão de justiça. Desse modo, a pretensão de correção estabelece uma conexão necessária entre o Direito e a moral. Segundo Alexy, isso leva a um segundo problema. O que é legal e o que é eficaz pode ser determinado por fatos sociais; porém, como se pode determinar o que é correto?

A resposta de Alexy a essa pergunta é que o correto e, portanto, o que é justo, pode ser determinado por meio da razão. Como se trata de correção normativa, o meio adequado de se determinar o que é correto é a razão prática. Segundo Alexy, tão polêmico quanto saber o que é razão prática é saber se ela existe:

\footnotetext{
${ }^{1}$ ATIENZA, Manuel. Entrevista a Robert Alexy. Doxa, Cuadernos de filosofía Del derecho. Alicante, n. 24,2001 , p. 34.
} 
Pero ahora resulta que no solo es polémico saber lo que es la razón práctica, sino también si simplemente existe. Recordemos simplemente la «Crítica del llamado conocimiento práctico», escrita por Alf Ross en el año 1933. A la pregunta de si existe la razón práctica, mi respuesta es que los discursos prácticos racionales resultan posibles. Lo que son los discursos prácticos racionales puede explicitarse a través de un sistema de reglas y de formas de la argumentación racional. Esta interpretación de la razón como argumentación, por lo tanto, de la práctica de dar y de promover razones, está expuesta a la objeción de que una tal interpretación puede ciertamente salvar la idea de la razón práctica, pero tiene que pagar por ello un alto precio: la pérdida de contenido. ${ }^{2}$

Assim, Alexy considera os discursos práticos racionais possíveis, os quais consistem em um sistema de regras de argumentação racional. Essa interpretação da razão como argumentação, então, pode preservar a ideia da razão prática, no entanto, em contrapartida, pode acarretar a perda de conteúdo.

Chega-se, assim, ao problema da conexão entre Direito e razão. Alexy considera a objeção quanto à perda de conteúdo um exagero. A interpretação da razão como argumentação significa, sem dúvida, uma procedimentalização, contudo, para ele, não exclui todo o conteúdo normativo.

Em sua teoria do discurso, que será oportunamente analisada, Alexy defende que o reconhecimento mútuo dos participantes no discurso como livres e iguais, além de ser um requisito da argumentação, é a base para se fundamentar os direitos humanos. Entretanto, ele sustenta que não basta fundamentar, mas que é preciso assegurar esses direitos em nível internacional, supranacional e nacional. Garantir esses direitos nesses três níveis significa que é preciso positiva-los. Em nível nacional, mais importante para a análise aqui desenvolvida, significa transformá-los em direitos fundamentais, o que, segundo ele, consiste na primeira conexão entre Direito e razão ${ }^{3}$.

A segunda conexão decorre da formalidade das regras e formas do discurso, contra a qual se dirige a objeção da perda de conteúdo. Alexy admite que, em muitos casos, essas regras e formas não permitem chegar a um resultado. Contudo, afirma que isso não faz com que elas percam seu valor, apenas anuncia a necessidade de vinculação das estruturas da argumentação com as estruturas de decisão. Para ele, esse é o lugar sistemático do Estado constitucional democrático:

\footnotetext{
${ }^{2}$ ATIENZA, op. cit., p. 35.

${ }^{3}$ ATIENZA, op. cit., p. 36.
} 
El Estado constitucional democrático supone la mejor forma de conectar la argumentación con la decisión desde la perspectiva de los ideales de libertad e igualdad fundamentados discursivamente. (...) Ahí juega un papel esencial la ponderación en cuanto forma de aplicación de los derechos fundamentales. De esta manera, cabría llamar «institucionalización de la razón» a este sistema completo en formación. ${ }^{4}$

Dessa exposição do pensamento de Alexy, podemos chegar a pressupostos fundamentais que guiam sua teoria. Para ele, há uma relação necessária entre Direito e moral, que é expressa por meio da pretensão de correção inserta no conceito de Direito. Essa pretensão de correção ou de justiça é determinada por meio da razão que, para Alexy, é a argumentação, definida por métodos e procedimentos considerados racionais. Esse método é sistematizado na teoria da argumentação jurídica, a qual tem como ponto central a ponderação que, nas palavras do próprio Alexy, é um sistema completo que pode ser considerado a "institucionalização da razão".

Cabe-nos destacar, portanto, o importante papel que o método desempenha na teoria do direito desenvolvida por Alexy. As regras e procedimentos argumentativos, para ele, além de garantirem a racionalidade, garantem a justiça das decisões judiciais. Cumpre analisarmos aqui quais as consequências e implicações dessas afirmações. Seria mesmo o método de Alexy eficaz para garantir racionalidade às decisões judiciais? Ou, ainda, é possível aferir a justiça de uma decisão a partir de critérios objetivos?

É esse, então, o caminho que pretendemos percorrer. Passaremos à análise dos fundamentos da teoria da argumentação jurídica e de seus principais desdobramentos.

\subsection{Teoria da argumentação jurídica}

Segundo Alexy, a teoria da argumentação jurídica visa solucionar o problema de como justificar plenamente um julgamento jurídico. Para tanto, ele sugere um "sistema de proposições, do qual se possa deduzir as premissas

\footnotetext{
${ }^{4}$ ATIENZA, op. cit., p. 36.
} 
normativas necessárias para os propósitos de justificação" ${ }^{5}$. Trata-se, portanto, de um sistema axiológico-teleológico, um sistema de princípios gerais de ordem jurídica.

Surge, então, o problema de como esses princípios podem ser estabelecidos e de como eles podem ser aplicados para justificação de julgamentos jurídicos. Esse sistema axiológico-teleológico não permite decisão única sobre o peso e equilíbrio dos princípios jurídicos ou sobre quais valores particulares devem ser priorizados em um dado caso concreto $^{6}$. Mas, segundo Alexy, isso não significa que seja impossível argumentar com base nesse sistema.

De acordo com ele, em casos em que a decisão não decorra logicamente de afirmações empíricas nem das normas pressupostas de um sistema jurídico, quem decide deve escolher entre várias soluções possíveis. A escolha da pessoa que decide é que determina qual proposição normativa singular deve ser afirmada ou promulgada como julgamento em um caso ${ }^{7}$. Essa escolha envolve, portanto, um julgamento de valor:

Uma tal ação de preferência, no entanto, exige um julgamento de que a alternativa escolhida em algum sentido é melhor do que outra e, neste ponto, propicia a base de um julgamento de valor. ${ }^{8}$

Alexy afirma, portanto, que seu método, apesar de racional, não é capaz de apresentar apenas uma única resposta ao caso concreto. O próprio método permite que o julgador escolha uma entre várias respostas possíveis, o que implica deixar o juiz livre para decidir da forma que melhor the convier. Isso ocorre porque a única forma de controle e racionalidade empregada por Alexy é o próprio método que legitima as decisões judiciais.

O julgador irá se orientar por julgamentos de valor, que ele considera moralmente corretos, para tomar suas decisões. Segundo Alexy, é errado concluir, a partir da teoria da argumentação jurídica, que há espaço livre para as próprias convicções morais subjetivas do aplicador do direito. Isso somente seria possível se

\footnotetext{
${ }^{5}$ ALEXY, Robert. Teoria da argumentação jurídica. Tradução de Zilda Hutchinson Schild Silva. São Paulo: Landy Editora, 2001, p. 18.

${ }^{6}$ ALEXY, Ibidem, p. 19.

${ }^{7}$ ALEXY, Ibidem, p. 20.

${ }^{8}$ ALEXY, Idem.
} 
não houvesse nenhuma possibilidade de avaliação objetiva. Assim, para ele, o próprio método também seria eficaz para garantir que as próprias convicções morais do aplicador do direito não contaminassem sua decisão.

Aliás, muito mais que isso. Para Alexy, a teoria da argumentação jurídica é necessária para que os juízes possam se precaver de arbitrariedades no processo de decisão que, segundo ele, envolve julgamentos de valor em um ato de cognição inevitavelmente discricionário.

\begin{abstract}
A tarefa de administrar a justiça segundo a lei às vezes pode exigir, em particular, que esses julgamentos de valor inerentes à ordem constitucional, mas que não tem nenhuma expressão ou apenas expressão imperfeita nos textos recentes de lei devem ser revelados e realizados nas decisões atuais por um ato de cognição que inevitavelmente envolve um ato discricionário. Os juízes devem se precaver contra arbitrariedades nesse processo; suas decisões têm de ser fundamentadas na argumentação racional. Deve ficar evidente que a lei escrita não cumpre a tarefa de prover uma justa resolução dos problemas legais. Nesses casos, a decisão judicial fecha a brecha de acordo com os padrões da razão prática e dos conceitos de justiça bem fundamentados da comunidade. ${ }^{9}$
\end{abstract}

Por conseguinte, Alexy acredita que a teoria da argumentação jurídica não só é capaz de garantir a racionalidade e a justiça das decisões, como também é capaz de evitar que arbitrariedades sejam cometidas pelo juiz. Porém, dizer que o ato decisório é inevitavelmente discricionário - o qual é baseado em julgamentos de valor - e afirmar que ele não está disponível às arbitrariedades do juiz é, no mínimo, contraditório. O que Alexy defende é um método de decisão que, ao mesmo tempo, confere poderes ilimitados ao juiz e tenta se justificar dizendo que não é capaz de fazer aquilo que, na verdade, é o seu ponto de partida. A teoria da argumentação jurídica, portanto, coloca o juiz no centro do poder decisório, como único participante e legitimado a dizer o que é o direito.

Alexy continua a construção da teoria da argumentação jurídica apresentando-a como caso especial do discurso prático geral, com o objetivo de desenvolver critérios para a racionalidade do discurso jurídico.

Quando Alexy diz que a teoria do discurso jurídico é um caso especial significa que a argumentação jurídica possui peculiaridades, mas que é subordinada ao discurso prático geral. Ambos os discursos se preocupam com questões práticas, isto é, com o que deve ou não ser feito ou deixado de fazer e ambos discutem

\footnotetext{
${ }^{9}$ ALEXY, op. cit., p. 34.
} 
questões com exigência de correção. A diferença é que o discurso jurídico ocorre sob algumas limitações ${ }^{10}$. São condições limitadoras a legislação, a consideração dos precedentes, a dogmática usada pela ciência do Direito, a sujeição às regras de ordem processual e as limitações de tempo ${ }^{11}$.

Compreender a argumentação jurídica como um caso especial significa, ao fim, identificar a argumentação jurídica com a argumentação moral. Trata-se, portanto, de mais um ponto de convergência entre a teoria do direito de Alexy e a axiologia jurídica.

A partir dessa concepção da argumentação jurídica como caso especial, Alexy analisa diversas teorias, entre elas de Stevenson, Hare, Toulmain, Baier e Habermas. Os resultados dessas discussões são integrados numa teoria geral do discurso prático racional, que possui vinte e duas regras e seis formas de argumentos.

Em razão de sua extensão e densidade, não há como esmiuçarmos aqui todas as regras e formas de argumentação expostas na teoria da argumentação jurídica de Alexy. O importante é compreendermos seu significado. Trata-se de uma teoria que se pretende científica, racional e justa, mas que, por trás do seu método, permite que os direitos e garantias previstos constitucionalmente fiquem sujeitos aos julgamentos de valor que os juízes "devem" emitir ao tomarem suas decisões. É nesse sentido que a teoria do direito defendida por Alexy é uma teoria axiológica, pois interpreta um caso a partir de pressupostos valorativos, atribuindo-Ihes pesos e medidas.

O juiz é, portanto, a chave do discurso do direito. Como suas decisões devem ter por fundamento julgamentos de valor, cabe a ele afirmar o que é a justiça e enunciar o fundamento moral dos direitos. Desse modo, os valores que serão os pontos de partida para a decisão são os valores do próprio juiz, cabendo a ele apenas justificá-los pelo método. O problema dessa lógica é que os direitos acabam se reduzindo apenas àquilo que o juiz diz que eles são, de modo que a democracia acaba sendo corrompida. Os direitos constitucionalmente assegurados acabam tendo seu peso normativo diluído à medida que os juízes os tratam como valores e estabelecem o grau em que esses princípios constitucionais devem ser cumpridos.

\footnotetext{
${ }^{10}$ ALEXY, op. cit., p. 212.

${ }^{11}$ ALEXY, op. cit., p. 27.
} 


\title{
2.3 A ponderação
}

Alexy desenvolve a ponderação como método decisório a ser aplicado diante de casos concretos. Antes de analisarmos, porém, seu conceito e estrutura, apresentaremos a compreensão de Alexy sobre a base do sistema normativo.

Segundo ele, princípios e regras são espécies do gênero "norma". As regras são "mandatos definitivos", pois ordenam consequências jurídicas definitivas, ou seja, se uma regra é aplicável, deve-se fazer exatamente o que ela determina. Sua aplicação é uma questão de tudo-ou-nada. Os princípios, por sua vez, são "mandatos de otimização", pois ordenam que algo se realize na maior medida possível segundo possibilidades fáticas e jurídicas:

\begin{abstract}
Las reglas son normas que, cuando se cumple el tipo de hecho, ordenan una consecuencia jurídica definitiva, es decir, cuando se cumplen determinadas condiciones, ordenan, prohíben 0 permiten algo definitivamente o autorizan definitivamente hacer algo. Por lo tanto, pueden ser llamadas 《rmandatos definitivos》. Su forma de aplicación característica es la subsunción. En cambio, los principios son mandatos de optimización. En tanto tales, son normas que ordenan que algo se realice en la mayor medida posible según las posibilidades fácticas y jurídicas. Esto significa que pueden ser realizados en diferente grado y quela medida de su realización depende no solo de las posibilidades fácticas sino también jurídicas. Las posibilidades jurídicas de la realización de un principio están determinadas esencialmente, a mas de por las reglas, por los principios opuestos. Esto último significa que los principios dependen de y requieren ponderación. La ponderación es la forma característica de la aplicación de los principios. ${ }^{12}$
\end{abstract}

Como explica Leonardo Barbosa, o conflito entre regras remete a um problema de validade. Duas regras em conflito, por exemplo, não podem valer simultaneamente no mesmo sistema jurídico. Desse modo, elas serão aplicadas por um método de subsunção e a solução se dará pela exclusão de uma das regras ou pela construção de uma "cláusula de exceção". A colisão de princípios, por sua vez, não suscita um problema quanto a sua validade, mas quanto ao seu peso. É aqui

\footnotetext{
${ }^{12}$ ALEXY, Robert. El Concepto y la Validez delDerecho. Tradução de Jorge M. Seña. $2^{\underline{a}}$ ed. Barcelona: Editoria Gedisa, 2004, p. 75.
} 
que surge a ponderação como método racional para solucionar a colisão entre princípios $^{13}$.

Segundo Alexy, em uma situação em que princípios estão em colisão, a solução consiste na determinação de uma relação de precedência referida às circunstâncias do caso. Dessa forma, o princípio que tem precedência restringe as possibilidades jurídicas da satisfação do princípio deslocado. Em algum outro caso, é possível que a relação de precedência seja invertida. A solução dependerá do peso relativo dos princípios opostos ${ }^{14}$.

Nesse ponto, Alexy faz uma importante observação a respeito de sua teoria. Ele diz que o comportamento dos princípios em colisão deixa claro que existe, entre princípios e valores, uma ampla coincidência estrutural. Desse modo, toda colisão de princípios pode ser apresentada como uma colisão de valores e viceversa:

Toda colisión de principios puede ser presentada como una colisión de
valores y toda colisión de valores como una colisión de principios. La única
diferencia reside en el hecho de que en las colisiones de principios de lo
que se trata es de que ha de ser en definitiva lo debido mientras que en la
solución de una colisión de valores a lo que se responde es, en definitiva,
que es lo mejor. Una pauta que dice que es lo debido, es decir, que es lo
ordenado, lo prohibido o lo permitido, tiene un carácter deontológico. En
cambio, si dice que es bueno o malo o mejor o peor, tiene un status
axiológico ${ }^{15}$.

Mais uma vez, Alexy confirma uma leitura axiológica do sistema jurídico. Em sua teoria do direito, os princípios possuem sua força normativa corroída ao serem vistos como "mandatos de otimização", cuja efetivação se dará na medida do possível e apenas isso. Essa leitura axiológica dos direitos constitucionais faz com que Alexy conclua que os princípios e valores tendem a colidir e que esse conflito somente pode ser solucionado pela ponderação.

A ponderação ou balanceamento começou a ser delineada pela Corte Constitucional Federal alemã com a decisão proferida no caso Lüth, em 1958. Lüth

${ }^{13}$ BARBOSA, Leonardo. Colisão de direitos fundamentais sob a perspectiva da teoria da argumentação jurídica: um diálogo entre Robert Alexy, Klaus Günther e Jürgen Habermas. Brasília, 2003. Documento não publicado, p. 6.

${ }^{14}$ ALEXY, Robert. El Concepto y la Validez delDerecho. Tradução de Jorge M. Seña. $2^{a}$ ed. Barcelona: Editoria Gedisa, 2004, p. 164.

${ }^{15}$ ALEXY, Idem. 
havia incentivado o boicote a filmes produzidos por um diretor nazista de grande destaque. A Corte considerou, a partir da perspectiva do balanceamento, que ao princípio da liberdade de expressão devia ser dado prioridade sobre considerações constitucionais concorrentes.

Segundo Alexy, do caso foram extraídas três ideias que marcaram o direito constitucional alemão: (i) os valores ou princípios dos direitos constitucionais aplicam-se não somente à relação entre o cidadão e o Estado, mas muito além disso, à "todas as áreas do Direito"; (ii) devido à essa aplicabilidade ampla, os direitos constitucionais tornam-se onipresentes e (iii) valores e princípios tendem a colidir. Uma colisão entre princípios, como dito, somente poderia ser resolvida pelo balanceamento. Desse modo, Alexy afirma a necessidade de um "balanceamento de interesses"16.

O caso Lüth, então, deixa em evidência, do ponto de vista metodológico, a contraposição entre o enfoque do balanceamento e o da subsunção. Alexy considera que o balanceamento é a construção que fornece maior racionalidade ao controle de constitucionalidade.

Segundo Alexy, no direito constitucional alemão, a ponderação ou o balanceamento é uma parte do que é requerido por um princípio mais abrangente, o princípio da proporcionalidade. Esse é subdividido, então, em princípios que expressam a ideia de otimização: os princípios da adequação, da necessidade e da proporcionalidade em sentido estrito ${ }^{17}$. Alexy utiliza-se da nomenclatura "princípios", mas ele se refere a regras sobre como um conflito entre normas deve ser interpretado.

Os dois primeiros princípios dizem respeito ao que é factualmente possível. Segundo o princípio da adequação, se um meio adotado para promover um princípio ou uma finalidade não é adequado, ele deve ser excluído caso esteja obstruindo a realização de um segundo princípio. Assim, a exclusão desse meio não acarretará prejuízos a nenhum dos dois princípios considerados no caso. Nas palavras de Alexy:

\footnotetext{
${ }^{16}$ ALEXY, Robert. Direitos Fundamentais, Balanceamento e Racionalidade. Tradução de Menelick de Carvalho Neto. Ratio Juris, v. 16, n. 2, jun. 2003, p. 3.

${ }^{17}$ ALEXY, Ibidem, p. 5.
} 
Se um meio $M$, adotado para promover o princípio $P 1$, não é adequado a essa finalidade, mas obstruí a realização de $P 2$, então não haverá custos quer para $P 1$ ou $P 2$ se $M$ for omitido, mas haverá custos para $P 2$ se $M$ for adotado. Então, $P 1$ e $P 2$, tomados conjuntamente, podem ser realizados em um grau mais alto relativamente ao que é factualmente possível se $M$ for abandonado. $P 1$ e $P 2$, quando considerados conjuntamente, proíbem o uso de $M^{18}$.

O princípio da necessidade, por sua vez, requer que, se há dois meios igualmente adequados para promover um princípio, deve ser escolhido aquele que interfira de forma menos gravosa no segundo princípio considerado no caso.

O princípio da proporcionalidade em sentido estrito significa a otimização em relação às possibilidades jurídicas. Esse princípio coincide com a Lei da Ponderação, que prescreve: "quanto maior o grau de não-satisfação ou de detrimento de um princípio, maior a importância de se satisfazer outro" ${ }^{19}$. Segundo Alexy, essa regra reforça a tese de que a otimização relativa de princípios opostos consiste na ponderação desses princípios.

Essas regras e, em particular, a Lei da Ponderação expressam as três etapas do balanceamento. A primeira consiste em estabelecer o grau de não satisfação ou de detrimento do primeiro princípio; a segunda estabelece a importância de satisfazer o princípio concorrente e a terceira etapa, finalmente, responde à questão de saber se a importância de se satisfazer ou não o princípio concorrente justifica o detrimento ou a não-satisfação do primeiro ${ }^{20}$.

A partir da compreensão das etapas e procedimentos da ponderação, é possível concluir que, ao julgador do caso, não cabe somente deliberar sobre a incidência de um princípio, mas sobre sua gradação e eficácia. Afirmar que princípios incidem de forma gradativa, para além de esvaziar ainda mais a força deontológica dos princípios, significa afirmar que cabe ao juiz decidir o que é justo e em que grau é justo. Isso significa atribuir ao julgador plenos poderes para decidir o que é moral. A decisão produzida será, portanto, valorativa, não dirá a respeito do que é correto, mas a respeito do que é bom, melhor ou pior. Isso pode ser facilmente percebido quando Alexy se utiliza de exemplos concretos para explicar e justificar o seu método.

\footnotetext{
${ }^{18}$ ALEXY, op. cit., p. 6.

${ }^{19}$ ALEXY, Idem.

${ }^{20}$ ALEXY, Idem.
} 
Como primeiro exemplo, Alexy trata de uma decisão da Corte Constitucional Federal alemã sobre alertas de possíveis danos à saúde em relação ao tabaco. Alexy afirma ser possível fixar uma escala com estágios "leve", "moderada" e "séria" quanto à intensidade de interferência na liberdade de profissão dos produtores de tabaco. O dever de colocar alertas à saúde quanto ao risco de fumar pode ser considerada uma interferência "leve" e o banimento dos produtos do tabaco ou a proibição de sua produção pode ser considerada uma interferência "séria". As mesmas escalas podem ser estabelecidas no que se refere aos motivos concorrentes.

Para Alexy, os riscos à saúde resultantes do tabaco são altos. Assim, na ponderação relativa a esse caso concreto, o grau de importância das razões de interferência é considerada alta e a intensidade de interferência no direito dos produtores de tabaco como "leve". Assim, tem-se como resultado da ponderação a proteção do direito à saúde ${ }^{21}$.

Os riscos para a saúde resultantes do fumo são altos. As razões justificadoras da interferência, portanto, pesam muito. Desse modo, se a intensidade de interferência é estabelecida como menor, e o grau de importância das razões para interferência como alta, o resultado ao se examinar a proporcionalidade em sentido estrito pode muito bem ser descrita - como a Corte Constitucional de fato o fez - como "óbvia".

Como segundo exemplo, Alexy trata de um clássico conflito entre o princípio da liberdade de expressão e os direitos da personalidade. Trata-se do caso em que uma revista satírica chamada Titanic descreveu um oficial paraplégico como "assassino nato" e, em uma edição posterior, como "aleijado". A Corte determinou, então, a intensidade de interferência entre esses direitos. A descrição "assassino nato" foi considerada como uma interferência moderada no direito de personalidade, já que no mesmo contexto outras pessoas tinham sido descritas com apelidos "engraçados" como o Presidente Federal, descrito como "cidadão nato". A interferência na liberdade de expressão com o pagamento de uma indenização alta foi considerada "grave"22.

\footnotetext{
${ }^{21}$ ALEXY, op. cit., p. 7.

${ }^{22}$ ALEXY, op. cit., p. 8.
} 
O problema, no entanto, foi diferente quando o oficial foi chamado de "aleijado", já que o adjetivo teria uma conotação "humilhante". O tribunal constitucional considerou um dano "sério" ao direito de personalidade do paraplégico. A importância de se proteger o oficial por uma indenização foi, então, considerada "grande". Assim, a séria interferência na liberdade de expressão foi contraposta à grande importância reconhecida à proteção do direito à personalidade ${ }^{23}$.

Assim, Alexy defende que princípios constitucionais podem ser graduados e medidos à conveniência dos julgadores do caso, pois, no fim das contas, ele entende princípios apenas como valores. Princípios, para ele, são fluidos e plásticos, cabendo aos julgadores decidir o que é moralmente relevante para a comunidade.

Além disso, Alexy acredita que todas as regras e fórmulas que ele apresentou, notadamente a "regra da proporcionalidade" seriam "razões" para decidir um determinado caso em certa direção. Essas regras que proporcionam juízos sobre graus de intensidade e proporcionalidade seriam, portanto, a garantia de justiça daquela decisão:

Essa regra, que pode ser denominada "Regra da Desproporcionalidade",
cria uma relação entre juízos sobre graus de intensidade e juízos sobre
proporcionalidade. Juízos sobre graus de intensidade são razões para o
julgamento sobre a proporcionalidade. Juízos sobre proporcionalidade
levantam, como todos os juízos, uma pretensão à correção, e essa
pretensão se apóia e se confirma em juízos sobre os graus de intensidade
enquanto razões. O que é suficiente para calçar o argumento de que o
balanceamento não retira ninguém do terreno da justificação e da
correção. $^{24}$

Há, ainda, outro problema desse método decisório. Pela ponderação, Alexy também intenta encontrar uma racionalidade que ele possa apreender para além das especificidades do caso concreto. A ponderação pretende chegar a uma relação de precedência entre princípios que possa ser tomada como uma regra geral, de modo a pré-definir as circunstâncias de colisão de princípios para casos futuros. Alexy se preocupa, portanto, em equilibrar, em abstrato, esses princípios colidentes.

\footnotetext{
${ }^{23}$ ALEXY, loc. cit., p. 8.

${ }^{24}$ ALEXY, loc. cit., p. 9.
} 
Alexy reconhece que cada caso possui suas próprias peculiaridades, porém, busca encontrar uma racionalidade geral e abstrata que possa ser aplicada a uma generalidade de casos. É por isso que Alexy nega a possibilidade de existir apenas uma resposta correta para cada caso concreto. Essa busca de respostas abstratas pode ser compreendida também como uma busca cega pela garantia da segurança, da certeza e da racionalidade.

Há, porém, dois detalhes aos quais Alexy não se atentou. Primeiro, é o juiz, e não o método, que define quais valores devem prevalecer. Segundo, a busca incessante da racionalidade por meio do método apenas atesta a irracionalidade do produto final.

\subsection{Algumas considerações}

A ponderação como método apto a garantir a racionalidade de decisões judiciais já recebeu amplas críticas de diversos autores, entre elas, aquelas desenvolvidas por Habermas.

Segundo o filósofo, são dois os problemas principais da teoria do direito desenvolvida por Alexy. A primeira crítica é relativa ao poder normativo dos direitos fundamentais. Segundo Habermas, a abordagem do balanceamento retiraria o poder normativo desses direitos, pois eles seriam reduzidos ao nível de fins, objetivos, política e valores. Isso significa, para Habermas, a destruição da compreensão deontológica das normas e princípios jurídicos. Segundo o filósofo, a esse risco de diluição dos direitos constitucionais haveria também o risco de produção de decisões irracionais já que admite não haver critérios racionais no método da ponderação ${ }^{25}$.

A segunda objeção é referente a um problema conceitual. Segundo Habermas, a ponderação acarretaria a perda de correção das decisões judiciais já que tal método não seria suficiente para "justificar" os resultados produzidos:

Habermas sustenta que o enfoque da ponderação subtrairia as decisões judiciais do reino definido por conceitos como os de certo (right) e errado

\footnotetext{
${ }^{25}$ ALEXY, loc. cit., p. 4.
} 
(wrong), de correção e incorreção, do domínio da justificação, para o reino definido por conceitos como adequado e inadequado, para o campo da descrição. Habermas afirma que o "sopesamento de valores" é capaz de produzir um juízo em relação ao seu "resultado", mas que não seria capaz de "justificar" esse resultado ${ }^{26}$.

Alexy admite que, se Habermas estiver correto, tratar-se-ia de um golpe fatal contra a ponderação, já que o Direito vincula-se necessariamente a uma pretensão de correção. Assim, admite que se o método da ponderação for incompatível com a correção e a justificação, ele não pode fazer parte do Direito ${ }^{27}$.

Sobre a primeira objeção de Habermas, Alexy afirma que essa seria plausível caso não fosse possível realizar juízos racionais acerca do método e da estrutura da ponderação. Ele se refere, por exemplo, à intensidade de interferência, aos graus de importância e à relação entre esses e os princípios ${ }^{28}$. Para demonstrar que tais juízos racionais são possíveis de modo a estabelecer um resultado racional por meio da ponderação, Alexy se utiliza da análise de exemplos.

Para responder à crítica de Habermas de que a ponderação de valores ocorre arbitraria ou irrefletidamente, Alexy apenas afirma que os supostos subjacentes aos juízos não são arbitrários e que o Tribunal se utiliza de bons argumentos. Assim, acredita que o enfoque do balanceamento subsiste à ambas as objeções de Habermas:

Mas os supostos subjacentes aos juízos sobre a intensidade da interferência na liberdade de expressão e no direito à personalidade não são arbitrários. A Corte Constitucional Federal trata da interferência na liberdade de expressão como séria, porque os juízos sobre indenização de danos poderiam reduzir a disposição futura dos afetados em produzirem sua revista do modo em que até então haviam feito. Esse é um argumento, e não é um argumento ruim. É altamente discutível se denominar alguém "assassino nato" efetivamente só representa uma interferência leve ou moderada. É difícil negar, no entanto, que a Corte aduziu razões para essa avaliação que, no mínimo, merecem consideração. Finalmente, a Corte considerou que a descrição do paraplégico como um "aleijado" configurava uma interferência intensa na liberdade de personalidade, sob o fundamento de que era humilhante e desrespeitosa. O que é, em primeiro lugar, um argumento, e, em segundo, um bom argumento. Daí não se poder dizer que o sopesamento tem lugar "arbitrariamente".

\footnotetext{
${ }^{26}$ ALEXY, loc. cit., p. 5.

${ }^{27}$ ALEXY, Idem.

${ }^{28}$ ALEXY, loc. cit., p. 7.

${ }^{29}$ ALEXY, loc. cit., p. 10.
} 
A crítica apresentada por Habermas apenas confirma a tese aqui defendida. Alexy se propõe a apresentar uma teoria que consiste basicamente num método decisório para garantir a racionalidade e a justiça das decisões judiciais. $\mathrm{O}$ problema é que o conjunto de regras apresentadas não só não cumpre o seu papel como se transforma num sistema decisório em que juízes, únicos autorizados a participar do direito, decidem a partir de seus próprios pressupostos morais, em um ato puramente discricionário. Na prática, são os juízes que definem os pressupostos valorativos e o método apenas cumpre a função de justificar a decisão já tomada $a$ priori. Os juízes se tornam verdadeiros "tutores morais" da sociedade ${ }^{30}$.

Dessa forma, Alexy corrompe o papel dos princípios e dos direitos e garantias fundamentais ao tratá-los como valores. Ele esquece, porém, que os valores da sociedade já foram previamente definidos pela Constituição, cabendo-nos apenas cumpri-los, tratando-os como normas, em seu conjunto deontológico.

A teoria da argumentação jurídica e a ponderação, apesar de detalhadas e bem-estruturadas, não são capazes de impedir que o livre-arbítrio dos julgadores prevaleça, ao contrário, são eles que escolhem e valoram os pressupostos que serão utilizados para julgar cada caso, cujo resultado eles já escolheram, de antemão, antes mesmo de analisar as peculiaridades do caso concreto. A constante busca pela racionalidade foi capaz de produzir um resultado completamente às avessas: é o próprio método que atesta a irracionalidade da decisão.

\footnotetext{
${ }^{30}$ Essa expressão é utilizada por Ingeborg Maus. Trataremos posteriormente do significado dessa expressão.
} 


\section{DEONTOLOGIA JURÍDICA: ESTRUTURA DA TEORIA DO DIREITO DE RONALD DWORKIN}

\subsection{Uma teoria geral do direito e as críticas ao positivismo jurídico}

Ronald Dworkin, por sua vez, desenvolveu uma teoria do direito que pode ser contraposta àquela defendida por Alexy. Ele apresenta uma teoria deontológica dos direitos e garantias fundamentais. É nesse sentido que analisaremos as bases e fundamentos da teoria do direito por ele desenvolvida.

Dworkin propõe uma teoria geral do direito que, segundo ele, é também uma teoria liberal ${ }^{31}$. Desse modo, Dworkin defende que uma teoria geral deve ser, ao mesmo tempo, normativa e conceitual. A parte normativa deve examinar temas variados e deve conter uma teoria da legislação, da decisão judicial e da observância da lei, ou seja, deve tratar questões do direito a partir da perspectiva de um legislador, de um juiz e de um cidadão comum.

Além disso, uma teoria geral do direito deve conter assuntos que não pertencem a nenhuma dessas categorias ou que pertencem a mais de uma. No que diz respeito às questões conceituais, Dworkin analisa se os princípios mais fundamentais da Constituição podem ser considerados como partes integrantes do direito. A partir dessa questão, outros problemas de legitimidade e jurisdição surgirão. Para ele, "se os princípios políticos inscritos na Constituição fazem parte do direito, a prerrogativa dos juízes de decidir o que determina a Constituição fica confirmada, pelo menos prima facie" ${ }^{32}$.

\footnotetext{
${ }^{31}$ Para Dworkin, o liberalismo é uma moral política constitutiva, que permaneceu a mesma ao longo de certo tempo e que continua influente. São posições políticas do liberalismo, entre outras, a diminuição da desigualdade de riquezas e a sua redistribuição por tributos progressivos; a intervenção do governo na economia para promover a estabilidade econômica, controlar a inflação, reduzir o desemprego e fornecer serviços; mas os liberais preferem uma intervenção pragmática e seletiva a uma substituição da livre empresa por decisões inteiramente coletivas. Desse modo, cabe notar que o liberalismo, no direito norte-americano, está ligado à tradição de direitos constitucionais fundamentais, à ideia de direitos como garantias contra a maioria. Portanto, o liberalismo no direito norte-americano nada tem a ver com o liberalismo no Brasil, que tem relação direta com os ideais conservadores e com o liberalismo econômico.
}

${ }^{32}$ DWORKIN, Ronald. Levando os direitos à sério. Tradução de Nelson Boeira. São Paulo: Martins Fontes, 2002, p. X. 
Ao mesmo tempo, Dworkin é profundamente crítico de uma teoria que muitos consideram como liberal. Em razão de sua popularidade e influência, ela é por ele considerada como teoria dominante do direito, a qual é dividida em duas partes independentes: o positivismo jurídico e o utilitarismo.

Para Dworkin, o positivismo é uma teoria sobre o que é o direito e sobre as condições necessárias e suficientes para a verdade de uma proposição jurídica. Segundo ele, o positivismo sustenta "que a verdade das proposições jurídicas consiste em fatos a respeito das regras que foram adotadas por instituições sociais específicas e em nada mais do que isso". A segunda parte, o utilitarismo, é uma teoria sobre o que o direito deve ser e sobre o modo como as instituições jurídicas devem comportar-se. Ela sustenta "que o direito e suas instituições deveriam estar a serviço do bem-estar geral e tão somente isso" ${ }^{\text {33. }}$.

Uma das principais críticas feitas por Dworkin à teoria dominante do direito diz respeito ao fato de o positivismo jurídico considerar que os indivíduos só possuem direitos criados por decisões políticas ou práticas sociais expressas:

O positivismo jurídico rejeita a ideia de que os direitos jurídicos possam
preexistir a qualquer forma de legislação; em outras palavras, rejeita a ideia
de que indivíduos ou grupos possam ter, em um processo judicial, outros
direitos além daqueles expressamente determinados pela coleção de regras
jurídicas que formam a totalidade dos direitos de uma comunidade. O
utilitarismo econômico rejeita a ideia de que os direitos políticos possam
preexistir aos direitos jurídicos, isto é, que os cidadãos possuam outra
justificativa para criticar uma decisão legislativa que não seja a alegação de
que uma decisão não atende, de fato, ao bem-estar geral ${ }^{34}$.

Outra importante objeção está relacionada à rejeição, pela teoria dominante, da ideia de que os indivíduos tem direitos contra o Estado, anteriores aos direitos criados pela legislação explícita.

O grande ataque de Dworkin ao positivismo, porém, diz respeito a como essa teoria compreende diferentes padrões do sistema jurídico. O positivismo é um modelo de e para um sistema de regras, que ignora o papel importante desempenhado por padrões que não são regras e que operam de forma diferente.

Dworkin apresenta como principais padrões do sistema jurídico os princípios, as políticas e as regras. "Política" é o padrão que estabelece um objetivo

\footnotetext{
${ }^{33}$ DWORKIN, op. cit., p. VIII.

${ }^{34}$ DWORKIN, op. cit., p. XIV.
} 
a ser alcançado, em geral, uma melhoria em algum aspecto econômico, social ou político de alguma comunidade. Já os "princípios" não visam promover ou assegurar uma dada situação econômica, mas são uma exigência de justiça ou equidade ou alguma outra dimensão da moralidade ${ }^{35}$.

A distinção entre princípios e regras é de natureza lógica. Ambos apontam decisões particulares, mas distinguem-se quanto à natureza da orientação oferecida. As regras são aplicáveis à maneira tudo-ou-nada. "Dados os fatos que uma regra estipula, então, ou a regra é válida, e neste caso a resposta que ela fornece deve ser aceita, ou não é válida, e neste caso em nada contribui para a

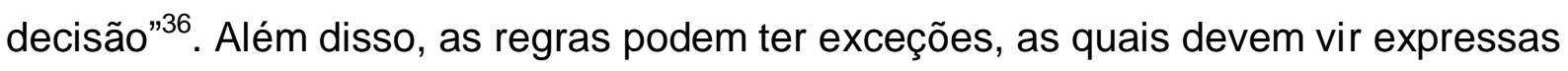
em seu enunciado, caso contrário, seriam incompletas.

Os princípios, por sua vez, não apresentam consequências jurídicas automáticas quando as condições são dadas. Eles não possuem exceções, mas contra-exemplos, os quais não devem vir em seu enunciado. Desse modo, um princípio não estabelece condições que tornam sua aplicação necessária, ao contrário, enuncia apenas "uma razão que conduz o argumento numa certa direção, mas [ainda assim] necessita uma decisão particular"37.

Há também outra diferença importante. Os princípios possuem a dimensão do peso ou importância. Quando se intercruzam, quem vai resolver o conflito deve considerar a força relativa de cada um. Dessa forma, faz sentido questionarmos que peso tem um princípio ou quão importante ele é.

Já as regras não possuem essa dimensão. Elas são funcionalmente importantes ou desimportantes quanto à regulação de um comportamento. No entanto, não é possível dizer que uma regra é mais importante que outra enquanto parte do mesmo sistema de regras, de tal modo que se duas regras estão em conflito, uma suplanta a outra em virtude de sua maior importância. Ao contrário, se duas regras estão em conflito, uma delas não pode ser válida ${ }^{38}$.

Após a conceituação desses diferentes padrões, é importante destacar o papel por eles desempenhado para a formulação de decisões jurídicas

\footnotetext{
${ }^{35}$ DWORKIN, op. cit., p. 36.

${ }^{36}$ DWORKIN, op. cit., p. 39.

${ }^{37}$ DWORKIN, op. cit., p. 41.

${ }^{38}$ DWORKIN, op. cit., p. 43.
} 
específicas. Para Dworkin, há duas orientações a respeito do direito e dos princípios. Na primeira, os princípios são considerados como parte do direito e eles devem ser tratados como regras jurídicas, no sentido de que possuem obrigatoriedade de lei e de que devem ser levados em conta por juízes. É a concepção defendida por Dworkin.

A segunda orientação não considera os princípios como parte do direito. Eles são padrões extralegais que o juiz tem a liberdade de aplicar, se assim o desejar. Desse modo, os princípios não são obrigatórios da mesma forma que as regras são. Trata-se da concepção de direito defendida pelo positivismo jurídico ${ }^{39}$.

Para Dworkin, a escolha da abordagem determina a resposta que será dada à questão. Na primeira, os juízes estão aplicando padrões jurídicos obrigatórios e, por isso, estão aplicando direitos e obrigações. Na segunda, os juízes tomam decisões por meio de um ato discricionário.

\begin{abstract}
A primeira alternativa trata os princípios como obrigatórios para os juízes, de tal modo que eles incorrem em erro ao não aplica-los quando pertinente. A segunda alternativa trata os princípios como resumos daquilo que os juízes, na sua maioria, 'adotam como princípio' de ação, quando forçados a ir além dos padrões aos quais estão vinculados. ${ }^{40}$
\end{abstract}

Segundo Dworkin, para os positivistas, decidir com base em seu poder discricionário significa que "quando um juiz esgota as regras a sua disposição, ele não está obrigado por quaisquer padrões derivados da autoridade da lei, ou seja, os padrões jurídicos que não são regras e são citados pelos juízes não impõem obrigações a eles" ${ }^{\prime 4}$. Assim, para os positivistas, os princípios não podem ser obrigatórios e não podem valer como lei, pois sua autoridade e importância são controversas.

Dworkin ataca a doutrina do poder discricionário dos juízes. Para ele, "a menos que alguns princípios sejam considerados obrigatórios pelos juízes e considerados como necessários para se chegar a uma decisão, nenhuma regra ou muito poucas seriam consideradas obrigatórias para eles". Dworkin afirma que, se os tribunais tivessem o poder discricionário para mudar as regras estabelecidas, essas

\footnotetext{
${ }^{39}$ DWORKIN, op. cit., p. 47.

${ }^{40}$ DWORKIN, op. cit., p. 49.

${ }^{41}$ DWORKIN, op. cit., p. 55.
} 
não seriam obrigatórias para eles e certamente não haveria direito, nos termos do modelo positivista ${ }^{42}$.

É possível traçarmos aqui um paralelo entre a teoria do direito de Alexy e a de Dworkin. Alexy não chega a negar que os princípios existem ou que esses fazem parte do Direito, como o faz os positivistas. Ao contrário, a definição de regras e princípios para Alexy e Dworkin em muitos pontos se assemelham. Regras são aplicáveis à maneira tudo-ou-nada e princípios possuem pesos e importância. Qual é, portanto, a diferença para esses dois autores?

A diferença é a forma como esses padrões serão orientados em uma decisão jurídica. Para Alexy, os princípios serão aplicados pelo método da ponderação em busca de uma "regra geral" que possa ser também aplicada a outros casos "semelhantes". A resposta de Dworkin ainda será esmiuçada e melhor elaborada, porém, é apenas diante das especificidades do caso concreto que podemos falar de aplicação, pesos e importância de princípios.

A teoria de Alexy é uma teoria sofisticada. Ela afirma reconhecer que os princípios fazem parte do direito, no entanto, esvazia o significado desses padrões. A teoria da argumentação jurídica apresenta consequências muito parecidas com a teoria positivista, para a qual os princípios não são obrigatórios e as decisões são tomadas por meio de um ato discricionário do juiz. Isso ocorre, portanto, não porque Alexy não os reconhece como parte do direito, mas porque ao valorar, graduar e ponderar princípios eles perdem sua força obrigatória e, por isso, perdem sua essência.

Dworkin, porém, não só adota o conceito que considera os princípios como parte do direito, mas afirma que princípios possuem obrigatoriedade de lei e que, por isso, devem ser observados pelos juristas, em sua força deontológica. Dworkin, portanto, nega a teoria positivista, a doutrina do poder discricionário e a teoria axiológica do direito defendida por Alexy.

\footnotetext{
${ }^{42}$ DWORKIN, op. cit., p. 59.
} 


\title{
3.2 Como os juízes devem decidir?
}

Antes de adentrarmos propriamente no tema do método decisório defendido por Dworkin, cabe explicarmos o papel que as convicções políticas devem desempenhar nas decisões sobre o que é o direito, bem como, sobre como os juízes devem compreender os direitos fundamentais em relação à concepção de Estado de Direito defendida por Dworkin.

Dworkin rejeita a concepção popular, mas irrealista, de que as convicções políticas não devem ter nenhuma influência sobre as decisões jurídicas. Desse modo, rejeita a ideia de que direito e política pertençam a mundos completamente diferentes e independentes, mas também rejeita a ideia oposta de que direito e política sejam a mesma coisa, ou seja, a ideia de que juízes que decidem casos difíceis estão simplesmente votando sua convicção jurídica pessoal como se fossem legisladores ${ }^{43}$.

Há dois fundamentos, segundo Dworkin, para rejeitarmos a ideia de que direito e política se confundem. O primeiro afirma que os juízes apenas devem impor convicções políticas que acreditam, de boa-fé, poder figurar em uma interpretação geral e coerente da cultura jurídica e política da comunidade. Segundo ele:

\begin{abstract}
Naturalmente, os juristas podem, razoavelmente, discordar sobre quando essa condição é satisfeita, e convicções muito diferentes, até mesmo contraditórias, podem passar pelo teste. Mas, algumas não. Um juiz que aceita esse limite e cujas convicções são marxistas ou anarquistas, ou tiradas de alguma tradição religiosa excêntrica, não pode impor essas convicções à comunidade com o título de Direito, por mais nobres ou iluminadas que acredite que sejam, pois elas não se podem prestar à interpretação geral e coerente de que ele necessita. ${ }^{44}$
\end{abstract}

Esse primeiro fundamento será posteriormente aprofundado. Quanto ao segundo fundamento, essa visão do direito e da política ignora a distinção entre diferentes argumentos que buscam justificar uma decisão política: os argumentos de política e os argumentos de princípio.

\footnotetext{
${ }^{43}$ DWORKIN, Ronald. Uma questão de princípio. Tradução de Luís Carlos Borges. São Paulo: Martins Fontes, 2001, p. IX.

${ }^{44}$ DWORKIN, Ibidem, p. IX.
} 
Os argumentos de política exigem que uma decisão particular promova alguma concepção do bem-estar geral ou do interesse público. Desse modo, são argumentos baseados no objetivo, pois tentam demonstrar que a comunidade estaria melhor se um programa particular fosse seguido. Os argumentos de princípio, ao contrário, recorrem os direitos políticos de cidadãos individuais. Assim, são argumentos baseados em direitos, que afirmam que determinado programa deve continuar ou deve ser abandonado, em razão do seu impacto sobre direitos individuais, mesmo que a comunidade como um todo fique pior ${ }^{45}$.

A visão correta, segundo Dworkin, é a de que os juízes devem julgar casos controversos baseando-se em argumentos de princípio e não de política. Assim, quando um juiz decide valendo-se de fundamentos políticos não significa que a decisão seja apenas a que grupos políticos desejariam, mas uma decisão tomada sobre o fundamento de que certos princípios de moralidade política são corretos ${ }^{46}$.

Dworkin analisa se essas decisões baseadas em convicções políticas não produziriam decisões mais "conservadoras". A conclusão a que ele chegou foi contrária. Juízes que tomam decisões valendo-se de convicções políticas devem fundamenta-las e devem demonstrar seu caráter político como uma decisão sobre direitos individuais e não do bem-estar geral. Segundo Dworkin, "decisões supostamente neutras dão mais efeito às convicções pessoais do juiz do que teria permitido uma decisão francamente influenciada por convicções políticas" 47 .

Novamente, em traço comparativo com a teoria do direito proposta por Alexy, cabe fazermos um destaque. Dworkin defende a ideia de que as decisões jurídicas devem ser influenciadas pelas convicções políticas dos juízes. No entanto, rejeita a ideia de que direito e política ou mesmo que direito e moral se confundem, como ocorre na teoria de Alexy. Para Dworkin, as convicções políticas não só devem ser coerentes com a cultura jurídica e política da comunidade, como devem ser justificadas por argumentos de princípio.

Alexy, ao confundir direito e moral e ao confundir princípios e valores, permite que juízes votem suas convicções morais como se legisladores fossem. Ou seja, Alexy permite que questões jurídicas sejam decididas a partir de argumentos

\footnotetext{
${ }^{45}$ DWORKIN, op. cit., p. 6.

${ }^{46}$ DWORKIN, op. cit., p. 3.

${ }^{47}$ DWORKIN, op. cit., p. 35-36.
} 
de política, que são sempre valorativos. Desse modo, as questões que deviam ser discutidas pelo legislativo são transferidas de forma indevida ao judiciário, que passam a decidir questões sobre direitos e garantias fundamentais esvaziando o conteúdo e a força normativa conferida pela Constituição, já que se fazem "substituir" por legisladores, ao adotar um discurso axiológico.

Quanto ao Estado de Direito, Dworkin afirma existir duas concepções. A primeira delas é a "centrada no texto legal", segundo a qual o poder nunca deve ser exercido contra cidadãos individuais, a não ser em conformidade com regras explícitas, até que essas sejam mudadas. Para ele, é uma concepção muito restrita, pois não estipula nada a respeito do conteúdo das regras que podem ser colocadas no texto jurídico ${ }^{48}$.

A segunda concepção, "centrada nos direitos", pressupõe que os cidadãos têm direitos e deveres morais entre si e direitos políticos perante o Estado como um todo. É essa a concepção de Estado de Direito defendida por Dworkin:

\begin{abstract}
Insiste que esses direitos morais e políticos sejam reconhecidos no Direito positivo, para que possam ser impostos quando da exigência de cidadãos individuais por meio de tribunais e outras instituições judiciais do tipo conhecido, na medida em que isso seja praticável. $O$ Estado de Direito dessa concepção é o ideal de governo por meio de uma concepção pública precisa dos direitos individuais. ${ }^{49}$
\end{abstract}

Ao defender essa concepção, Dworkin aborda a questão sobre a moralidade do direito e afirma um sistema de direitos contramajoritários. Ele defende que esses direitos são trunfos políticos, que não podem ser negados em razão de um objetivo comum da coletividade:

Os direitos individuais são trunfos políticos que os indivíduos detêm. Os indivíduos têm direitos quando, por alguma razão, um objetivo comum não configura uma justificativa suficiente para negar-lhes aquilo que, enquanto indivíduos, desejam ter ou fazer, ou quando não há uma justificativa suficiente para lhes impor alguma perda ou dano. ${ }^{50}$.

Esses direitos têm como objetivo a dignidade humana e a igualdade política. Assim, Dworkin questiona se o Estado estaria legitimado a punir um

\footnotetext{
${ }^{48}$ DWORKIN, Loc. cit., p. 6.

${ }^{49}$ DWORKIN, op. cit., p. 7.

${ }^{50}$ DWORKIN, op. cit., p. XV.
} 
indivíduo que viola uma lei que tenta invalidar algum direito fundamental. Para ele, há casos em que tal punição não seria justificada.

Desse modo, Dworkin afirma a impossibilidade de se alegar o interesse geral de uma comunidade para restringir tais direitos. Segundo ele, um Estado que leve os direitos a sério deve "abrir mão da ideia de que os cidadãos nunca tem o direito de violar a lei e não deve definir os direitos dos cidadãos de modo que possam ser anulados por supostas razões de bem-estar geral ${ }^{151}$.

Defender o sistema de direitos e normas fundamentais como um sistema contramajoritário, significa dizer, portanto, que os indivíduos possuem direitos contra os demais cidadãos e contra o Estado. Essa visão corrobora o que afirma Dworkin quanto à impossibilidade de se decidir questões jurídicas a partir de argumentos de política. Se o papel do direito é garantir direitos fundamentais, como poderia o direito cumprir esse objetivo utilizando-se de argumentos de política que são, em essência, argumentos valorativos e majoritários?

Dworkin defende, portanto, que o direito deve cumprir uma lógica diferente da lógica da política. A política será democrática à medida que as deliberações forem feitas de modo livre, de forma que a deliberação majoritária prevaleça. O direito, porém, será democrático à medida que os direitos forem exercidos contramajoritariamente. A visão axiológica do direito defendida por Alexy não só retira a força normativa dos direitos fundamentais ao trata-los com argumentos valorativos, como também corrompe o seu papel democrático.

\subsection{O direito como integridade}

Dworkin sustenta que a análise jurídica é fundamentalmente interpretativa. Como consequência dessa afirmação, sustenta que existe apenas uma resposta correta para um caso controverso. O positivismo nega essa afirmação e defende a posição cética de que não existem respostas corretas, mas apenas

\footnotetext{
${ }^{51}$ DWORKIN, Ronald. Levando os direitos à sério. Tradução de Nelson Boeira. São Paulo: Martins Fontes, 2002, p. 313.
} 
respostas diferentes para um caso concreto $^{52}$. Os aspectos em que se pode dizer que há apenas uma resposta correta são especiais e complexos. É o que analisaremos.

Dworkin elabora três concepções antagônicas da prática jurídica, que são organizadas em afirmações interpretativas. O convencionalismo é a mais vulnerável por defender que decisões jurídicas devem ser tomadas somente de maneira coerente com decisões anteriores, esgotadas pela previsibilidade. $O$ pragmatismo jurídico, por sua vez, é uma concepção cética que defende que os juízes devem tomar decisões que lhes pareçam melhores para o futuro da comunidade, ignorando qualquer forma de coerência com o passado ${ }^{53}$.

O direito como integridade, por fim, sustenta que direitos e responsabilidades decorrem de decisões anteriores, não só quando estão implícitos nessas decisões, mas quando procedem de princípios de moral política que essas decisões explícitas pressupõem. Essa é a concepção defendida por Dworkin.

Existem dois princípios de integridade política: "um princípio legislativo, que pede aos legisladores que tentem tornar o conjunto de leis moralmente coerente, e um princípio jurisdicional, que demanda que a lei, tanto quanto possível, seja vista como coerente nesse sentido" ${ }^{54}$. Como dito, a ideia de se interpretar o direito como um conjunto moralmente coerente, é um dos fundamentos para a concepção de que direito e política não se confundem e de que um juiz deve utilizarse de convicções políticas para decidir casos jurídicos.

$\mathrm{Na}$ política comum, a integridade deve ser vista como um ideal independente e autônomo, pois é possível que eventualmente entre em conflito com outros ideais políticos como a equidade e a justiça. No campo da política, a integridade impede a tomada de decisões conciliatórias por parte dos legisladores. Essas são decisões que mostram incoerência de princípio e que são justificadas em bases arbitrárias. São soluções que salvam alguns indivíduos, escolhidos

\footnotetext{
${ }^{52}$ DWORKIN, Ronald. Uma questão de princípio. Tradução de Luís Carlos Borges. São Paulo: Martins Fontes, 2001, p. XI.

${ }^{53}$ DWORKIN, Ronald. O império do direito. Tradução de Jefferson Luiz Camargo. São Paulo: Martins Fontes, 2007, p. 119.

${ }^{54}$ DWORKIN, Ibidem, p. 213.
} 
arbitrariamente, de uma injustiça que outros continuarão sofrendo. Segundo Dworkin, elas são as mais clamorosas violações do ideal da integridade ${ }^{55}$.

Assim, para Dworkin, uma sociedade política que reconhece a integridade como virtude se transforma em uma forma especial de comunidade. A integridade é atraente, pois possui valor prático e indicativo - protege contra a parcialidade, a fraude e outras formas de corrupção oficial, além de contribuir para a eficiência do direito:

Se as pessoas aceitam que são governadas não apenas por regras explícitas, estabelecidas por decisões políticas tomadas no passado, mas por quaisquer outras regras que decorrem dos princípios que essas decisões pressupõem, então o conjunto de normas públicas reconhecidas pode expandir-se e contrair-se organicamente, à medida que se tornem mais sofisticadas em perceber e explorar aquilo que esses princípios exigem sob novas circunstâncias, sem a necessidade de um detalhamento da legislação ou da jurisprudência de cada um dos possíveis pontos de conflito. ${ }^{56}$

Uma comunidade que reconhece a integridade deve, então, ser uma comunidade de princípio, ou seja, deve aceitar que são governadas por princípios comuns e não apenas por um acordo político. Assim, cada um aceita a integridade política como um ideal político distinto e trata a aceitação geral desse ideal como um dos componentes da comunidade, mesmo entre pessoas que de outra forma estariam em desacordo sobre a moral política ${ }^{57}$.

Desse modo, Dworkin defende a integridade como chave para a melhor interpretação construtiva de nossas práticas jurídicas distintas e, principalmente, do modo como os juízes devem decidir casos difíceis. A integridade não significa coerência, no sentido de que os juízes devem repetir as decisões anteriores da forma mais fiel possível, mas no sentido de que devem considerar as normas públicas como um sistema único e coerente de justiça e equidade na correta proporção ${ }^{58}$. Assim, a integridade é uma norma dinâmica, na medida em que

\footnotetext{
${ }^{55}$ DWORKIN, op. cit., p. 220-224.

${ }^{56}$ DWORKIN, op. cit., p. 229.

${ }^{57}$ DWORKIN, op. cit., p. 254-255.

${ }^{58}$ DWORKIN, op. cit., p. 264.
} 
incentiva o juiz a ser mais abrangente e imaginativo na busca de coerência com o princípio fundamental $^{59}$.

Para Dworkin, entender o direito como integridade e, portanto, como um sistema coerente de normas e princípios constitucionais significa, ao contrário do que afirma Alexy, que princípios não são passíveis de colisão. Para Dworkin, princípios apenas se tencionam, pois o direito exige que o juiz os aplique em sua integridade, por mais contraditórios que aparentam ser. Essa tensão, ou aparente colisão entre normas constitucionais, deverá ser solucionada no caso concreto. Somente no contexto e na especificidade do caso é que o julgador poderá dizer qual princípio ou norma constitucional é mais adequada.

Para Alexy, princípios são vistos como valores e, por isso, são passíveis de colisão. Ao ponderar uma colisão entre princípios, ele exclui um princípio parcial ou totalmente para poder aplicar o princípio oposto também parcial ou totalmente. Para Alexy, não aplicar um princípio significa considera-lo como inválido. Para Dworkin, porém, a precedência ou a aplicabilidade de um princípio só pode ser aferida apenas e tão somente para um caso concreto. Para Dworkin, princípios não são ponderáveis nem sacrificáveis entre si, um princípio não pode prevalecer diante do outro, apenas diante do caso. Não se pode pretender, como o faz Alexy, que a resposta para um caso seja geral e abstrata, válida também para outros casos "semelhantes".

\subsection{O método decisório do juiz Hércules}

As três concepções de direito apresentadas por Dworkin são teorias interpretativas. No entanto, há diferenças entre elas. O convencionalismo e o pragmatismo jurídico são teorias que se oferecem como interpretações, recomendam estilos ou programas de deliberação judicial que não são, em si, programas de interpretação. Ou seja, essas teorias não exigem que os juízes façam novos exames, essencialmente interpretativos, da doutrina jurídica. $O$ convencionalismo, por exemplo, exige que os juízes estudem registros

\footnotetext{
${ }^{59}$ DWORKIN, op. cit., p. 265.
} 
parlamentares para descobrirem que decisões foram tomadas no passado. Ao longo desse processo, porém, surgirão novos problemas interpretativos ${ }^{60}$.

O direito como integridade, contudo, é um programa de interpretação. É tanto o produto da interpretação da prática jurídica como sua fonte de inspiração, ou seja, é uma interpretação do direito e, ao mesmo tempo, o ponto de partida para as futuras interpretações que os juízes devem fazer.

O programa que apresenta aos juízes que devem decidir casos difíceis é essencialmente, não apenas contingentemente, interpretativo; o direito como integridade pede-lhe que continuem interpretando o mesmo material que ele próprio afirma ter interpretado com sucesso. Oferece-se como a continuidade - e como a origem - das interpretações mais detalhadas que recomenda. $^{61}$

Em relação ao método decisório que o direito como integridade recomenda a juízes diante de casos difíceis, Dworkin compara a interpretação do direito com a interpretação literária. Ele cita o exemplo de escritores que devem escrever um romance em cadeia. Cada autor deve interpretar o texto que recebeu e escrever o seu próprio capítulo, dando continuidade ao romance de modo que ele seja um todo coerente.

Dworkin afirma não ser tão fácil distinguir a etapa em que o romancista interpreta e a etapa em que ele acrescenta seu próprio texto. Afirma que o romancista deve se perguntar, ainda, qual interpretação torna a obra de arte melhor como um todo. Ao responder essa questão, ele irá utilizar algumas de suas crenças ou convicções para decidir qual interpretação deverá adotar ${ }^{62}$.

O direito como integridade pede ao juiz que se considere como um autor na cadeia do direito. Ele deve considerar as decisões de outros juízes como parte de uma história que ele tem de interpretar e continuar, de acordo com suas opiniões sobre o melhor andamento que deve ser dado à história em questão.

Para expor essa complexa estrutura da interpretação jurídica, Dworkin se utiliza de um juiz imaginário, o qual possui capacidade e paciência sobrehumanas e que aceita o direito como integridade. Seu nome é Hércules. Dworkin

\footnotetext{
${ }^{60}$ DWORKIN, op. cit., p. 272.

${ }^{61}$ DWORKIN, op. cit., p. 273.

${ }^{62}$ DWORKIN, op. cit., p. 282.
} 
adverte, porém, que não devemos supor que as respostas de Hércules a várias questões são uma definição do direito como integridade. São apenas respostas que, naquele momento, pareceram as melhores. O direito como integridade é uma abordagem que consiste mais em perguntas que em respostas, e outros juízes que também a aceitam poderiam dar repostas diferentes daquelas dadas pelo juiz Hércules $^{63}$.

O direito como integridade pede, então, que os juízes admitam que o direito é estruturado por um conjunto coerente de princípios sobre a justiça, a equidade e o devido processo legal adjetivo, e pede-lhes "que os apliquem nos novos casos que se lhes apresentem, de tal modo que a situação de cada pessoa seja justa e equitativa segundo as mesmas normas" ${ }^{64}$. Segundo Dworkin, esse estilo de decisão promove o ideal do direito como integridade que é ser uma comunidade de princípios.

O juiz Hércules deve interpretar o direito com a finalidade de mostra-lo em sua melhor luz possível. E essa interpretação deve encontrar, em algum conjunto coerente de princípios sobre direitos e deveres, a melhor interpretação da estrutura política e da doutrina jurídica de sua comunidade ${ }^{65}$.

Dworkin trata, então, de duas dimensões do juízo interpretativo, que se interagem de maneira complexa, a adequação e a justificação:

\begin{abstract}
No direito, porém, a exemplo do que ocorre na literatura, a interação entre adequação e justificação é complexa. Assim como num romance em cadeia, a interpretação representa para cada intérprete um delicado equilíbrio entre diferentes tipos de atitudes literárias e artísticas, em direito, é um delicado equilíbrio entre convicções políticas de diversos tipos; tanto no direito quanto na literatura, estas devem ser suficientemente afins, ainda que distintas, para permitirem um juízo geral que troque o sucesso de uma interpretação sobre um tipo de critério por seu fracasso sobre outro. ${ }^{66}$
\end{abstract}

A dimensão da adequação irá estabelecer um limiar aproximado que a interpretação de alguma parte do direito deve atender para tornar-se aceitável. Esse limiar irá eliminar interpretações que não são plausíveis, de modo que os fatos da

\footnotetext{
${ }^{63}$ DWORKIN, op. cit., p. 287.

${ }^{64}$ DWORKIN, op. cit., p. 291.

${ }^{65}$ DWORKIN, op. cit., p. 305.

${ }^{66}$ DWORKIN, loc. cit., p. 287.
} 
história jurídica irão limitar o papel que as convicções pessoais do juiz irão desempenhar em questões de justiça. Desse modo, uma interpretação de qualquer parte do direito deve considerar não somente as decisões tomadas por autoridades anteriores, mas também o modo como essas decisões foram tomadas, por quais autoridades e em que circunstâncias ${ }^{67}$.

Diferentes juízes, porém, irão estabelecer esse limiar de adequação de maneira diversa. Mas, segundo Dworkin, qualquer juiz que aceite o direito como integridade deve admitir que a história política de sua comunidade irá, às vezes, restringir suas convicções políticas em seu juízo interpretativo geral. Se isso não acontecer, ou se o juiz tiver como limiar de adequação apenas suas próprias convicções de justiça, ele não estará interpretando, mas agindo de má-fé.

\footnotetext{
Se não o fizer - se seu limiar de adequação derivar totalmente de suas concepções de justiça e a elas for ajustável, de tal modo que essas concepções ofereçam automaticamente uma interpretação aceitável -, não poderá dizer de boa-fé que está interpretando a prática jurídica. Como o romancista em cadeia, cujos juízos sobre adequação se ajustavam automaticamente a suas opiniões literárias mais profundas, estará agindo de má-fé ou enganando a si próprio. ${ }^{68}$
}

Quanto à dimensão de justificação, por exemplo, o judiciário deve agir de modo distinto do legislativo, o qual não precisa de razões de princípio para justificar as regras que aprova e que pode justificar suas decisões de criar novos direitos ao mostrar que esses irão contribuir para o bem-estar do conjunto da comunidade. Os juízes devem tomar suas decisões com base em princípios, não em política.

Então, diante de casos difíceis, que são aqueles em que uma interpretação de uma lei ou julgado não prevalece em uma análise preliminar, o juiz deverá escolher entre as interpretações aceitáveis, questionando qual delas apresenta as instituições e decisões da comunidade em sua melhor luz, do ponto de vista da moral política. Nesse caso, segundo Dworkin, as próprias convicções morais e políticas do juiz estarão diretamente engajadas e a decisão que ele deverá tomar é complexa:

\footnotetext{
${ }^{67}$ DWORKIN, op. cit., p. 292.

${ }^{68}$ DWORKIN, op. cit., p. 305.
} 
Mas, o julgamento político que ele deve fazer é em si mesmo complexo e, às vezes, vai opor uma parte de sua moral política a outra: sua decisão vai refletir não apenas suas opiniões sobre a justiça e a equidade, mas suas conviç̧ões de ordem superior sobre a possibilidade de acordo entre esses ideais que competem entre si. ${ }^{69}$

Desse modo, as diferentes dimensões do trabalho decisório de um juiz, as dimensões de adequação e justificação, são, em última análise, sensíveis ao seu juízo político. As decisões do juiz sobre questões preliminares ou sobre o conteúdo do direito são, portanto, políticas e não mecânicas.

\subsection{Algumas considerações}

A partir dessa concepção sobre a forma adequada como os juízes devem tomar decisões, Dworkin defende a tese de que somente é possível uma resposta correta em casos controversos.

Quem rejeita essa tese, em especial os céticos, afirma que juízes e advogados frequentemente discordarão sobre qual interpretação é mais equitativa ou mais justa, mas que nenhuma delas pode estar realmente correta, pois não existem padrões objetivos de justiça e equidade dos quais um observador neutro poderia se utilizar para decidir por uma delas ${ }^{70}$.

Os céticos argumentam também que a prática jurídica é muito contraditória para oferecer qualquer interpretação coerente. Segundo Dworkin, Hércules compreende que, em termos de princípios, o direito está longe de uma coerência perfeita. Porém, ele acredita que essas contradições não sejam intratáveis dentro de cada ramo do direito, ou seja, ele acredita que pode encontrar um conjunto de princípios razoavelmente plausíveis, dentro de cada ramo do direito, que permitam interpretações aceitáveis ${ }^{71}$.

Para Dworkin, cada caso concreto e cada aparente colisão entre princípios terá apenas uma resposta correta, o que significa dizer que o juiz não tem

\footnotetext{
${ }^{69}$ DWORKIN, op. cit., p. 306.

${ }^{70}$ DWORKIN, op. cit., p. 317.

${ }^{71}$ DWORKIN, op. cit., p. 319.
} 
a opção de escolher entre várias respostas possíveis; a única resposta correta será encontrada ao se compreender o direito em sua integridade. Poderemos saber se o juiz, de fato, chegou a essa resposta a partir da sua justificação diante do caso concreto, que deve estar de acordo com o sistema coerente de princípios da comunidade política. Para Dworkin, se a tese de que há apenas uma resposta correta para cada caso controverso estiver errada, será correto concluir que o juiz tem poder discricionário para decidir em qualquer sentido ${ }^{72}$.

A partir da exposição da teoria do direito de Dworkin é possível compreender o que significa tratar os direitos fundamentais deontologicamente. Os direitos devem ser respeitados em sua integridade, devem ter sua força normativa preservada assim como a Constituição determina. Operar de forma deontológica significa excluir interpretações políticas majoritárias que visem prejudicar direitos fundamentais; significa limitar a influência de pretensões outras que não sejam exclusivamente jurídicas, como dos campos da política, da religião, da moralidade ou da economia. Significa dizer que as decisões judiciais devem ser tomadas com argumentos de princípio e não de política.

Quando se tem uma compreensão deontológica das normas constitucionais, a distinção inicial entre regras e princípios acaba sendo mitigada. Mesmo as regras acabam sendo aplicadas como princípios, pois terão sua incidência justificada no caso concreto, a partir de suas especificidades. Compreendidos deontologicamente, princípios são enunciados abertos que significam muito além do seu próprio texto.

O problema de se compreender direitos de forma axiológica é que os direitos passam a ser tratados como dados sociológicos em um jogo de opinião pública. Ao tratar princípios como valores, da forma como defende Alexy, o juiz estará substituindo o legislador e atuará valorando os direitos e princípios já valorados e já protegidos pela Constituição. Paradoxalmente, a axiologia acaba por esvaziar o valor que a Constituição pretendia proteger no debate político.

Em sua compreensão deontológica, portanto, não é possível falar em colisão entre princípios ou normas constitucionais. Eles são aparentemente contraditórios porque, na integridade, eles são coerentes. A responsável, portanto, pela coerência e integridade do direito é a Constituição. Desse modo, devemos

${ }^{72}$ DWORKIN, op. cit., p. 179. 
buscar interpretações que preservem o texto constitucional em sua integridade e que o afirmem principiologicamente. O que garantirá, portanto, a racionalidade das decisões jurídicas não será um método, mas a postura que o julgador terá diante do direito. É apenas tratando o direito em sua integridade que o juiz poderá garantir a justiça e a correção de suas decisões. 


\section{ANÁLISE DE CASO: O DIREITO DE GREVE DOS SERVIDORES PÚBLICOS}

\subsection{O direito de greve como direito à violência}

O direito de greve está relacionado, em sua origem, a um movimento de força por parte dos trabalhadores. Essa característica está presente no " 10 de maio" e na "Place de Grève", seus símbolos mais importantes ${ }^{73}$. O primeiro se tratou de um verdadeiro banho de sangue, quando líderes sindicais foram condenados e executados em uma luta pela jornada de oito horas.

A Place de Grève, por sua vez, representa o local de encontro entre o direito e a violência. No mesmo local onde o Estado realizava execuções públicas, os trabalhadores se encontravam e faziam suas reivindicações. É evidente o significado comum desses dois símbolos. A greve consiste em um instrumento de força, de luta.

O direito de greve é, então, o direito à violência. Segundo Jaques Derrida, trata-se da violência fundadora do direito, aquela capaz de "justificar, legitimar ou de transformar as relações de direito e, portanto, de se apresentar como um direito ao direito" ${ }^{74}$. Trata-se da violência que torna capaz o reconhecimento de uma determinada situação como lei, de determinada vontade como legítima.

O próprio conceito de direito implica a ideia de força. O direito é uma força autorizada, uma força justificada. Não é possível pensar num direito que não tenha aplicabilidade e não há aplicabilidade que não esteja relacionada à força. Não há direito, portanto, que não esteja intimamente relacionado à ideia de violência. Os grevistas colocam uma série de condições para a retomada ao trabalho e só encerram sua greve se uma ordem de coisas mudar. Há, ai, a violência contra a

\footnotetext{
${ }^{73}$ PINTO, Cristiano O. P. A.; LOURENÇO FILHO, Ricardo. A greve e sua conformação pelo TST: Desvelando Mentalidades. In: O mundo do trabalho, volume I: leituras críticas da jurisprudência do TST: em defesa do direito do trabalho. São Paulo: LTr, 2009, p. 65-67.

${ }^{74}$ DERRIDA, Jaques. Força de Lei. Tradução de Leyla Perrone-Moisés. São Paulo: Martins Fontes, 2010 , p. 81.
} 
violência ${ }^{75}$. O direito de greve é, portanto, um direito que se exerce contra o Estado, contra o próprio direito.

Mas, no que consiste essa violência do direito de greve? Segundo Derrida, a palavra Gewalt pode ser traduzida do alemão como violência, mas também pode ser traduzida como poder legítimo, como autoridade. Desse modo, Gewalt é, ao mesmo tempo, violência e poder legítimo, a autoridade justificada. A violência do direito de greve refere-se, portanto, à "força de lei". Não se trata de uma autorização concedida à força violenta, injusta, sem regra ou arbitrária. Há, portanto, um caráter diferencial na força, que é a força "performativa":

Ora, a operação de fundar, inaugurar, justificar o direito, fazer a lei,
consistiria num golpe de força, numa violência performativa e, portanto,
interpretativa que, nela mesma, não é nem justa nem injusta, e que
nenhuma justiça, nenhum direito prévio e anteriormente fundador, nenhuma
fundação preexistente, por definição, poderia nem garantir, nem contradizer
ou invalidar. ${ }^{76}$

Trata-se, portanto, de uma força que é interpretativa e que se reflete num apelo à crença. Ela é capaz de interpretar e reinterpretar o direito existente, sendo, portanto, capaz de transformá-lo. Ao mesmo tempo, invoca a confiança, a crença por parte daqueles que respeitam a autoridade.

Há, desse modo, uma clara separação entre o direito e a justiça. Segundo Derrida, as leis não são justas em si próprias. Nós apenas as obedecemos não porque são justas, mas porque têm autoridade. As leis possuem, portanto, um "fundamento místico" para sua autoridade, que é justamente crédito que damos a elas $^{77}$.

Para Derrida, isso faz com que a origem da autoridade e a instauração da lei sejam uma violência sem fundamento, já que não podem apoiar-se em outra coisa, senão nelas mesmas. Isso não significa que a autoridade ou a lei sejam injustas em si, no sentido de "ilegais" ou "ilegítimas", significa apenas que elas não são nem legais nem ilegais no seu momento "fundador".

\footnotetext{
${ }^{75}$ DERRIDA, op. cit., p. 8.

${ }^{76}$ DERRIDA, op. cit., p. 24. Grifos do autor.

${ }^{77}$ DERRIDA, op. cit., p. 20-21.
} 
A partir dessas ideias, Derrida apresenta 0 direito como essencialmente desconstruível. Esses são também os fundamentos do direito de greve: "Assim, o direito é essencialmente desconstruível, ou porque ele é fundado, isto é, construído sobre camadas textuais interpretáveis e transformáveis, ou porque seu fundamento último, por definição, não é fundado" ${ }^{78}$.

A greve pretende, portanto, contestar a ordem do próprio direito. Tratase de um direito que visa contestar a ordem existente e criar uma situação revolucionária, a qual tratará de fundar um novo direito. A greve é, então, aquilo que suspende o direito. Ela interrompe a ordem do direito estabelecida para fundar outra, é uma instância de não-direito:

É o momento em que a fundação do direito fica suspensa no vazio ou em cima do abismo, suspensa a um ato performativo puro que não teria de prestar contas a ninguém e diante de ninguém. O sujeito suposto desse performativo puro não estaria mais diante da lei, ou melhor, ele estaria diante de uma lei ainda indeterminada, diante da lei como uma lei ainda inexistente, uma lei ainda por vir, ainda à frente e devendo vir ${ }^{79}$.

\subsection{0 direito de greve no ordenamento jurídico brasileiro}

No ordenamento jurídico brasileiro, o direito de greve possui status constitucional e está incluso entre os direitos fundamentais. O direito de greve dos trabalhadores em geral está previsto no art. 9ํ da Constituição Federal de 1988, que assegura aos próprios trabalhadores a decisão sobre a oportunidade de exercer tal direito e sobre os interesses que serão defendidos ${ }^{80}$. Os limites e parâmetros sob os quais o direito de greve dos trabalhadores em geral deve ser exercido na prática são

\footnotetext{
${ }^{78}$ DERRIDA, op. cit., p. 26. Grifos do autor.

${ }^{79}$ DERRIDA, op. cit., p. 84.

80 BRASIL, Constituição Federal, Art. 9o: "É assegurado o direito de greve, competindo aos trabalhadores decidir sobre a oportunidade de exercê-lo e sobre os interesses que devam por meio dele defender.§ $1^{\circ}$ - A lei definirá os serviços ou atividades essenciais e disporá sobre 0 atendimento das necessidades inadiáveis da comunidade. $\S 2^{\circ}$ - Os abusos cometidos sujeitam os responsáveis às penas da lei".
} 
previstos pela Lei de Greve (Lei 7.783/89), que regulamenta tal direito em âmbito infraconstitucional.

Quanto ao serviço público, o direito de greve é garantido pelo art. 37, inciso VII, da Constituição Federal de 1988. Esse mesmo dispositivo prevê que tal direito será exercido "nos termos e limites" estabelecidos em lei específica ${ }^{81}$. Ocorre, porém, que o direito de greve dos servidores públicos ainda não foi regulamentado em âmbito infraconstitucional, o que faz suscitar uma série de debates sobre a possibilidade de exercício desse direito.

Em muitas situações, o exercício do direito de greve pelos servidores públicos passou a ser visto como ilegal e a própria aplicabilidade do dispositivo constitucional passou a ser questionada. Diante de tal contexto, foram interpostos mandados de injunção perante o Supremo Tribunal Federal, diante da manifesta omissão do legislador, que "inviabilizava" o exercício de tal direito.

A primeira manifestação do STF sobre o tema ocorreu em 1994, com a decisão proferida nos autos do Mandado de Injunção no 20, proposto pela Confederação dos Servidores Públicos do Brasil. O STF entendeu que o direito de greve dos servidores públicos não poderia ser exercido enquanto não fosse regulamentado o art. 37 , inciso VII, da Constituição. Para o tribunal, o dispositivo constitucional foi considerado de eficácia meramente limitada ${ }^{82}$, de modo que a "mera outorga constitucional" de tal direito não bastava para garantir o seu imediato exercício. Na ocasião, o STF limitou-se a reconhecer a inércia do Poder Legislativo e a notificá-lo para que a omissão fosse suprida.

A partir de então, toda e qualquer a greve realizada por servidores públicos passou a ser considerada ilegal, até que a norma regulamentadora de tal direito fosse editada. Ao se pronunciar, o STF fez questão de ressaltar o caráter limitado do direito de greve ao observar que esse não pode prescindir da

\footnotetext{
${ }^{81}$ BRASIL, Constituição Federal,Art. 37: "A administração pública direta e indireta de qualquer dos Poderes da União, dos Estados, do Distrito Federal e dos Municípios obedecerá aos princípios de legalidade, impessoalidade, moralidade, publicidade e eficiência e, também, ao seguinte:VII - o direito de greve será exercido nos termos e nos limites definidos em lei específica."

${ }^{82}$ Essa classificação é proposta por José Afonso da Silva, que classifica as normas constitucionais, quanto à sua aplicabilidade, em plenas, contidas e limitadas. As normas de eficácia plena possuem aplicabilidade direta, imediata e integral, produzindo seus todos os seus efeitos desde logo; as normas de eficácia contida possuem aplicabilidade direta e imediata, mas não possuem aplicabilidade integral, pois podem sofrer futuras regulamentações do legislador infraconstitucional; por fim, as normas de eficácia limitada possuem aplicabilidade indireta, mediata e reduzida, em geral, dependem de futura legislação para efetiva aplicação.
} 
observância dos princípios da supremacia do interesse público, bem como, da continuidade dos serviços públicos.

Essa configuração do direito de greve se manteve até 2007, ocasião em que o STF pôde se pronunciar novamente sobre o direito de greve dos servidores públicos, alterando seu entendimento sobre tal direito e sobre as próprias configurações do mandado de injunção.

Não é difícil perceber a situação absurda que o direito de greve dos servidores públicos se encontra desde a promulgação da Constituição Federal de 1988. Tal direito foi inúmeras vezes esvaziado por diversas instâncias de poder até ser expressamente nulificado pelo STF, tribunal competente para salvaguardar a Constituição. O direito de greve é um direito fundamental do cidadão, pois é o direito de questionar a própria ordem jurídica, é o direito de fundar novos direitos.

Esse é, portanto, o objeto de estudo desse trabalho, cujo objetivo é analisar como o direito de greve foi e é tratado pelo Supremo Tribunal Federal. Busca-se compreender os fundamentos que justificam a compreensão e o tratamento de tal direito pelo STF. Como o STF compreende o direito de greve e quais os fundamentos que o levaram a decidir dessa forma? É essa a reflexão que pretendemos perseguir. Para tanto, utilizaremos as correntes filosóficas da deontologia e axiologia jurídica sobre como os juízes devem decidir para guiar nossa análise sobre o tema.

\subsection{O direito de greve dos servidores públicos e sua conformação pelo STF}

O Mandado de Injunção no 712 foi impetrado pelo Sindicato dos Trabalhadores do Poder Judiciário do Estado do Pará, com o objetivo de assegurar plena eficácia ao art. 37, VII, da Constituição, e de garantir o reconhecimento do exercício do direito de greve. A referida entidade sindical havia impetrado mandado de segurança contra ato da Presidência do Tribunal de Justiça do Estado do Pará para que fosse aprovada a revisão anual de remuneração dos servidores. Em razão da não apreciação de tal ação, a greve parcial foi, então, desencadeada. Diante da jurisprudência do próprio STF, a greve foi declarada ilegal e houve a suspensão dos pontos e desconto dos dias parados. 
A partir do julgamento do MI № 20 até o MI № 712, ou seja, durante treze anos, a jurisprudência predominante do STF limitou-se, como dito, a declarar a mora do legislador em editar a norma regulamentadora do direito de greve dos servidores públicos, de modo a esvaziar tal direito e o relegar à condição de total ilegalidade.

Isso porque o Tribunal classificou a norma do art. 37, VII, da CF, como de eficácia limitada, negando a auto-aplicabilidade desse dispositivo constitucional e condicionando o exercício de tal direito à edição da norma regulamentadora. Ocorre, porém, que a própria Constituição prevê o princípio da aplicabilidade imediata das normas definidoras de direitos e garantias fundamentais ${ }^{83}$. Não há dúvida de que o direito de greve seja uma garantia fundamental. Desse modo, essa compreensão revela a ausência de uma leitura deontológica da Constituição, que exige que tal direito tenha aplicabilidade direta e imediata. Segundo Dworkin, conceber a Constituição em sua força normativa significa compreender que princípios possuem força vinculante e que, por isso, devem ser obrigatoriamente considerados pelos juízes.

A expressão "nos termos e limites da lei" deve ser interpretada como possibilidade de posterior regulamentação pelo legislador infraconstitucional com objetivo de organizar, na prática, como tal direito deve ser exercido, mas não no sentido de condicionar o exercício de uma garantia constitucional à edição de tal norma. É evidente, portanto, a irregular classificação do direito de greve feita pelo STF quanto à sua eficácia, dado que a própria Constituição afirma a autoaplicabilidade de tais direitos e garantias fundamentais.

Ao imprimir tal interpretação ao direito de greve dos servidores públicos, o STF não só nulificou um direito assegurado constitucionalmente como foi capaz de transformar o mandado de injunção em um instrumento completamente inócuo, já que o mesmo tem a função principal de tornar viável o exercício de direitos e liberdades constitucionais diante da ausência de norma regulamentadora que viabilize o seu exercício ${ }^{84}$.

\footnotetext{
${ }^{83}$ BRASIL, Constituição Federal, Art. $5^{\circ}$, $\S 1^{\circ}$ : "As normas definidoras dos direitos e garantias fundamentais têm aplicação imediata".

${ }^{84}$ BRASIL, Constituição Federal, Art. 5ำ, LXXI: "Conceder-se-á mandado de injunção sempre que a falta de norma regulamentadora torne inviável o exercício dos direitos e liberdades constitucionais e das prerrogativas inerentes à nacionalidade, à soberania e à cidadania".
} 
Por ocasião do julgamento do $\mathrm{MI}$ no 712 , o tribunal continua a tratar a norma definidora do direito de greve dos servidores públicos como norma de eficácia limitada e afirma como objetivo do impetrante a "concessão de eficácia" a tal direito. Essa postura continua a revelar a ausência de uma leitura deontológica da Constituição, que exige a compreensão da Constituição em seu todo e em sua força normativa.

Pois bem. O tribunal supera a discussão a respeito da eficácia da norma afirmando que deverá se pronunciar no sentido de viabilizar o exercício do direito. Nesse sentido, o STF passa a apresentar a concepção por ele defendida em relação ao direito de greve dos servidores públicos.

Segundo o Min. Eros Grau, o direito de greve é a arma mais eficaz dos trabalhadores, que se consolida num poder de fato. Ele afirma se tratar de um direito fundamental de natureza instrumental, cuja auto-aplicabilidade, tal como formulado no art. 9º é inquestionável. Afirma, ainda, que a Constituição não prevê limitações ao tratar do direito de greve dos trabalhadores em geral, devendo a lei regulamentadora apenas protegê-lo, não sendo admitidas quaisquer limitações a tal direito. No entanto, os abusos decorrentes do exercício do direito de greve devem ser punidos. Cabe também à lei definir os serviços ou atividades essenciais e dispor sobre $\mathrm{o}$ atendimento das necessidades inadiáveis da comunidade ${ }^{85}$.

$\mathrm{O}$ art. 37, VII, que prevê o direito de greve dos servidores públicos, segundo o Min. Eros Grau, consiste em uma norma especial em relação ao caráter geral veiculado pelo art. 9o. O que se justifica, segundo ele, por duas razões. Primeiro porque, no serviço público, não há a tensão entre trabalho e capital como no âmbito da exploração da atividade econômica pelos particulares. Para o ministro, nesse caso, a greve coloca em risco interesses egoísticos do detentor do capital. O mesmo não ocorre no serviço público, no qual não há oposição direta entre interesses dos trabalhadores e interesses individuais, ou seja, a greve no serviço público comprometeria não interesses egoísticos, mas interesses sociais, dos cidadãos que necessitam da prestação do serviço público.

Em segundo lugar, afirma o Min. Eros Grau que a relação estatutária é instrumental do fornecimento de serviços públicos, cuja continuidade deve ser

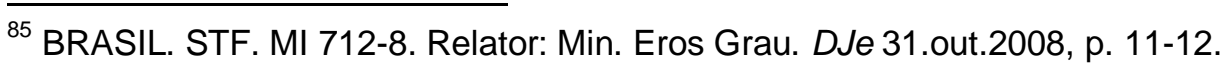


assegurada para benefício do todo social ${ }^{86}$. Afirma ele que o serviço público é definido pela Constituição como serviço existencial, ou seja, tem amplitude maior do que aquele serviço definido como essencial.

Ora, ocorre que os dois motivos apresentados pelo Min. Eros Grau para justificar a norma do art. 37, VII, como de caráter especial e, portanto, de eficácia limitada, não passam de argumentos de política, assim como definido por Ronald Dworkin. Um argumento de política exige que uma decisão promova alguma concepção de bem-estar geral ou do interesse público, visando proporcionar determinada melhoria para a sociedade como um todo.

Esses argumentos, porém, são adequados em processos de decisão política, típicos do Poder Legislativo. Ao decidir questões jurídicas, o Judiciário deve lançar mão apenas de argumentos de princípio, que são aqueles que recorrem a direitos de cidadãos individuais ou de uma coletividade de cidadãos. Sob a perspectiva da deontologia jurídica, um juiz, ao decidir uma questão jurídica, deve afirmar os direitos constitucionalmente previstos a esses indivíduos, mesmo que a comunidade como um todo fique pior. Isso ocorre porque os direitos fundamentais são contramajoritários, que são direitos que devem ser exercidos contra o Estado e a sociedade como um todo, o que significa que aos direitos fundamentais deve ser dada eficácia, mesmo que isso contrarie os interesses ou objetivos comuns da maioria.

Desse modo, não faz sentido a alegação, para o presente caso concreto, de que o direito de greve dos servidores públicos deve ficar condicionado à continuidade dos serviços públicos ou mesmo de que deve ser tratado como norma especial, pois prejudica interesses sociais. Ora, essa é a essência do direito de greve, assim como exposto por Derrida. A greve é o direito de suspender o direito, é o direito à violência, é o direito de perturbar. É a partir do incômodo provocado que o direito de greve se torna eficaz, que o que está sendo reivindicado é notado e se torna importante. O que seria o direito de greve sem a possibilidade de paralisação das atividades?

Condicionar o exercício de tal direito à necessidade de continuidade dos serviços públicos de forma indiscriminada ou mesmo à observação irrestrita dos interesses sociais significa esvaziar o próprio direito de seu conteúdo, de sua

${ }^{86}$ BRASIL.STF. MI 712-8. Relator: Min. Eros Grau. DJe 31.out.2008, p. 13. 
essência. O que não significa tratar o direito de greve como direito absoluto. Os abusos e excessos cometidos no exercício de tal direito devem ser coibidos. O direito de greve dos servidores públicos deve, sim, ser regulamentado. No entanto, regulamentar não significa tornar esse direito nulo, não significa restringi-lo mais do que a Constituição, lida em sua integridade, seja capaz de permitir.

Os argumentos utilizados pelo Min. Eros Grau revelam, portanto, uma leitura axiológica da Constituição, pois todo argumento de política é, em essência, um argumento valorativo e majoritário. Além disso, julgar com fundamento em argumentos valorativos significa votar uma convicção jurídica pessoal como se legislador fosse. Essa postura, não só retira a força normativa da Constituição, como corrompe o seu papel democrático.

No mesmo sentido, o Min. Gilmar Mendes afirma que, no caso do direito de greve dos servidores públicos, "afigura-se inegável o conflito existente entre as necessidades mínimas de legislação para o exercício do direito de greve dos servidores públicos, de um lado, com o direito a serviços públicos adequados e prestados de forma contínua, de outro" ${ }^{87}$.

Essa afirmação revela o tratamento de tal direito a partir da perspectiva da ponderação defendida por Robert Alexy. Isso porque o direito de greve e o direito à continuidade dos serviços públicos são tratados como conflitantes entre si, como princípios em colisão.

Tratar o direito de greve a partir da perspectiva da ponderação significa considera-lo como "mandato de otimização", cuja efetivação se dará apenas na medida do possível. Assumir essa perspectiva significa, portanto, admitir que cabe ao juiz deliberar sobre a incidência de um princípio, sua gradação e eficácia. E é justamente o que o STF defende para o caso. O direito de greve poderá ser exercido "enquanto for capaz de assegurar o princípio da continuidade dos serviços públicos". Sob o pretexto de aplicar o princípio da proporcionalidade, os ministros avocam a si a possibilidade de decidir o que é justo e em que grau é justo.

Tanto é assim, que o Min. Gilmar Mendes ressalta, em razão do "imperativo da continuidade dos serviços públicos" e diante das peculiaridades do caso concreto, a faculdade de o juiz impor a observância de regime de greve "mais

\footnotetext{
${ }^{87}$ BRASIL. STF. MI 712-8. Relator: Min. Eros Grau. DJe 31.out.2008, p. 53.
} 
severo" em razão de se tratarem de serviços e atividades essenciais ${ }^{88}$. Ora, essa afirmação corrobora uma leitura axiológica da Constituição, na medida em que cabe ao juiz definir, a partir da "severidade" do regime a ser imposto, o grau de eficácia em que o direito de greve deverá ser exercido.

Temos então como indispensável a definição, por essa Corte, das medidas a serem tomadas no sentido de assegurar a continuidade da prestação do serviço público; somente assim poderá ser conferida eficácia ao disposto no art. 37, VII. $^{89}$

Desse modo, o direito de greve dos servidores públicos acaba tendo sua força diluída à medida que é compreendido como valor e à medida que o seu grau de eficácia passa a ser definido pelos próprios ministros. O STF, assim, se define como competente para decidir questões de moralidade da sociedade. A resposta apresentada não define o que é correto em relação ao direito de greve e à forma como esse deve ser exercido, define, ao contrário, aquilo que é melhor para a sociedade como um todo.

Com o objetivo de garantir efetividade ao direito de greve dos servidores públicos e às próprias decisões proferidas pelo tribunal, o STF reformula o instituto do mandado de injunção. Segundo o Min. Eros Grau, a questão agora não diz respeito somente à eficácia do texto normativo do art. 37, VII, é importante questionar o próprio papel do STF, que tem se limitado a emitir decisões ineficazes, que solicitam ao Poder Legislativo que cumpra o seu dever, inutilmente ${ }^{90}$.

De acordo com o Min. Eros Grau, o mandado de injunção destina-se à remoção do obstáculo criado pela omissão do poder competente para a criação da norma regulamentadora, que deve ocorrer mediante a formação supletiva de tal norma pelo Poder Judiciário. Segundo ele, essa intervenção deve subordinar-se ao princípio da harmonia e divisão dos Poderes ${ }^{91}$. Para que isso seja possível, é preciso que esteja configurada a mora do legislador, diante da não regulamentação no prazo previsto ou, na sua ausência, no prazo que o tribunal competente entender

\footnotetext{
${ }^{88}$ BRASIL.STF. MI 712-8. Relator: Min. Eros Grau. DJe 31.out.2008, p. 55.

${ }^{89}$ BRASIL. STF. MI 712-8. Relator: Min. Eros Grau. DJe 31.out.2008, p. 25.

${ }^{90}$ BRASIL.STF. MI 712-8. Relator: Min. Eros Grau. DJe 31.out.2008, p. 11.

${ }^{91}$ BRASIL. STF. MI 712-8. Relator: Min. Eros Grau. DJe 31.out.2008, p. 17. As considerações feitas pelo Min. Eros Grau a respeito do mandado de injunção é extraída da justificativa de autoria do prof. José Ignácio Botelho de Mesquita a anteprojeto de lei por ele elaborado.
} 
como razoável. Há como pressuposto, portanto, um ato de resistência do Poder Legislativo em se cumprir o dispositivo constitucional.

O conteúdo e os efeitos da decisão que julga o mandado de injunção não estão previstos na Constituição, que se limita a estabelecer a sua hipótese de cabimento. Segundo o Min. Eros Grau, surge então a questão se a norma supletivamente formulada pelo tribunal deve regular apenas o caso concreto submetido ao tribunal ou se deve abranger a totalidade dos casos constituídos pelos mesmos elementos objetivos, embora entre sujeitos diferentes. Segundo o ministro, deve-se optar pela segunda alternativa, já que a atividade normativa deve ser pautada pelo princípio da isonomia:

\begin{abstract}
Dentre essas alternativas, é de se optar pela última, posto que a atividade normativa é dominada pelo princípio da isonomia, que exclui a possibilidade de se criarem tantas normas regulamentadoras diferentes quantos sejam os casos concretos submetidos ao mesmo preceito constitucional. Também aqui é preciso ter presente que não cumpre ao tribunal remover um obstáculo que só diga respeito ao caso concreto, mas a todos os casos constituídos pelos mesmos elementos objetivos. ${ }^{92}$
\end{abstract}

Desse modo, segundo o ministro, constitui poder-dever do STF elaborar a norma supletiva faltante, o que consistirá, portanto, no exercício de sua função normativa e não legislativa. Para ele, o argumento de que o STF estaria a legislar e, portanto, a ferir o princípio da separação dos poderes é insubsistente.

Segundo o Min. Eros Grau, dado o caráter especial da norma do art. 37, VII, não se pode cogitar que a Lei 7.783/89 seja aplicada, como tal, para regulamentar o exercício do direito de greve dos servidores públicos. Segundo ele, impõe ao STF traçar os parâmetros atinentes a esse exercício, os quais deverão ser definidos de modo abstrato e geral, para resolver casos análogos ${ }^{93}$.

Ora, a mudança de concepção do STF em relação ao instrumento do mandado de injunção é, em si, benéfica e muito importante para que a Constituição seja conformada em sua força normativa. O mandado de injunção foi constitucionalmente concebido com função de garantir efetividade a direitos fundamentais cuja ausência de norma regulamentadora inviabilizasse o exercício do mesmo. Contudo, a mudança de interpretação em relação a esse remédio

\footnotetext{
${ }^{92}$ BRASIL. STF. MI 712-8. Relator: Min. Eros Grau. DJe 31.out.2008, p. 19.

${ }^{93}$ BRASIL. STF. MI 712-8. Relator: Min. Eros Grau. DJe 31.out.2008, p. 25.
} 
constitucional era mais do que necessária dada a situação de total inocuidade em que esse instrumento se encontrava.

Apesar da virada de jurisprudência quanto ao mandado de injunção apresentar uma leitura deontológica da Constituição, devemos questionar os fundamentos pelos quais ela se deu. Entendemos como correta a competência do Poder Judiciário para formular normas supletivas, em sua função normativa. No entanto, os efeitos de tal decisão não devem extrapolar os limites do caso concreto.

A proposta apresentada pelo Min. Eros Grau tem fundamentos, portanto, em uma leitura axiológica da Constituição. Assim como as soluções apresentadas pelo método da ponderação, a proposta do STF pretende encontrar soluções para além das especificidades do caso concreto. $O$ objetivo do tribunal é criar uma norma geral que possa pré-definir uma relação de precedência para casos futuros entre a, assim definida, colisão do direito de greve dos servidores públicos e a continuidade de tais serviços. Assim como na ponderação, o STF se preocupa em equilibrar, em abstrato, esses princípios considerados colidentes.

Nesse sentido, argumenta o Min. Gilmar Mendes que o STF construiu jurisprudência no sentido de equiparar os efeitos das decisões proferidas no mandado de injunção e no controle abstrato da omissão, de modo que as decisões proferidas em ambos os remédios constitucionais devem ser dotadas de eficácia erga omnes ${ }^{94}$. Em sentido contrário, o Min. Sepúlveda Pertence afirma a necessidade de que a norma supletiva seja fixada para cada caso, para ele, se não for assim, o STF estará legislando.

O Min. Lewandowisk afirma aderir à corrente que admite a remoção, pelo Judiciário, do obstáculo da omissão legislativa, viabilizando o exercício do direito no caso concreto. No entanto, entende como inviável a expedição de regulamentos para disciplinar, em tese, determinada situação. Para o ministro, ao emprestar eficácia erga omnes ao mandado de injunção, o STF estaria intrometendo-se, de forma indevida, na esfera de competência conferida pela Constituição ao Poder Legislativo ${ }^{95}$.

\footnotetext{
${ }^{94}$ BRASIL.STF. MI 712-8. Relator: Min. Eros Grau. DJe 31.out.2008, p. 37-38.

${ }^{95}$ BRASIL. STF. MI 712-8. Relator: Min. Eros Grau. DJe 31.out.2008, p. 95-96.
} 
É esse, portanto, o entendimento a que nos filiamos. Admitir que o STF possa formular decisões que tenham caráter geral e abstrato, significa permitir que esse tribunal atue como legislador.

Segundo Dworkin, o direito deve ser compreendido em sua integridade, o que significa que as normas públicas devem ser consideradas como um sistema único e coerente de equidade e justiça. Desse modo, Dworkin defende a integridade como chave para a interpretação das práticas jurídicas e, principalmente, do modo como juízes devem decidir casos difíceis, como o caso em análise.

Assim, uma decisão para o caso do direito de greve dos servidores públicos que compreenda o direito como integridade não deve considerar esse direito, compreendido na forma de princípio constitucional, como em conflito com o princípio da continuidade dos serviços públicos. O direito como integridade entende esses princípios como conciliáveis e coerentes no sistema jurídico. Um princípio não deve excluir o outro de maneira abstrata.

Uma leitura deontológica da Constituição não admite que haja colisão entre princípios, em abstrato, ao contrário da axiologia jurídica. Segundo a perspectiva deontológica, os princípios apenas se tencionam. $\mathrm{O}$ direito, aplicado em sua integridade, revela que o conflito entre princípios é apenas aparente, pois, compreendidos em conjunto, tais princípios são coerentes. Para Dworkin, a precedência ou aplicabilidade de um princípio somente pode ser aferida no caso concreto, pois é apenas diante das circunstâncias e especificidades do caso que o julgador poderá dizer qual princípio ou norma constitucional será mais adequada.

Para Dworkin, princípios não são ponderáveis nem sacrificáveis entre si, um princípio não pode prevalecer diante do outro, apenas diante do caso. Não se pode pretender, como o faz Alexy, que a resposta para um caso seja geral e abstrata, válida também para outros casos "semelhantes". O direito como integridade, ao invés de pretender uma resposta geral, pede que os juízes admitam que o direito é estruturado por um conjunto coerente de princípios sobre a justiça, a equidade e o devido processo legal e pede-lhes que os apliquem nos novos casos que se thes apresentem, de tal modo que a situação de cada pessoa seja justa e equitativa segundo as mesmas normas. O juiz deve interpretar o direito com a finalidade de mostrá-lo em sua melhor luz possível.

Assim, preservar a força normativa dos princípios e direitos fundamentais assim como a Constituição determina implica em respeitar esses 
direitos em sua integridade. Operar o direito de greve dos servidores públicos de forma deontológica significa excluir interpretações políticas majoritárias que visem prejudicar o exercício desse direito fundamental. Significa limitar a influência de pretensões outras que não sejam exclusivamente jurídicas, como dos campos da política, da moralidade ou da economia. Significa dizer que as decisões judiciais devem ser tomadas com fundamentos de princípio e não de política.

\title{
4.4 Reflexos e consequências da decisão proferida no MI n 712
}

A solução delineada ao caso específico do direito de greve dos servidores públicos possui fundamentos em uma leitura axiológica da Constituição e não reconhece o valor do direito de greve em sua essência. $O$ raciocínio alexyano em torno do direito de greve retira do exercício desse direito sua natureza deontológica e o transforma num jogo de opinião pública. O STF revela o direito de greve dos servidores públicos como um direito limitado, pois é tratado como um problema valorativo, político, social, o qual é resolvido de um modo profundamente axiológico:

\begin{abstract}
A importância do direito de greve, contudo, não pode prescindir da necessária observância dos princípios da supremacia do interesse público e da continuidade dos serviços desenvolvidos pela administração estatal, especialmente aquelas atividades que, qualificadas pela nota da essencialidade, não podem sofrer, em hipótese alguma, qualquer tipo de interrupção ${ }^{96}$.
\end{abstract}

Isso ocorre, contudo, em razão do direito de greve se apresentar como uma ameaça à ordem jurídica, que é interna ao próprio direito. A forma como o STF apresenta o direito de greve revela esse temor, esse medo que o Estado tem da violência que é capaz de ameaçá-lo ou, até mesmo, de destruí-lo.

Segundo Derrida, o direito tende a proibir determinada violência e a condená-la na medida em que ela ameaça, não determinada lei, mas a ordem jurídica. É daí que nasce o interesse do direito em se instaurar e a conservar a si

${ }^{96}$ BRASIL.STF. MI 712-8. Relator: Min. Eros Grau. DJe 31.out.2008, p. 117. 
mesmo. É por isso, então, que o direito monopoliza a violência, não com a intenção de proteger determinados fins justos e legais, mas o próprio direito:

Falar de um interesse do direito pode parecer "surpreendente", é a palavra usada por Benjamin; mas é ao mesmo tempo normal, é da natureza de seu próprio interesse pretender excluir as violências individuais que ameaçam a sua ordem; é com vistas a seu interesse que ele monopoliza, assim, a violência no sentido de Gewalt, a violência enquanto autoridade ${ }^{97}$.

Tanto é assim que o Min. Gilmar Mendes sustenta que a regulamentação do direito de greve dos servidores públicos deve ocorrer para que se possa disciplinar "uma seara que hoje está submetida a um tipo de lei da selva". Segundo o ministro, a regulamentação do direito não é bem vista nem pelos servidores, que temem a disciplina do tema, nem pelos representantes governamentais, que entendem que a regulamentação acabaria por criar o direito de greve dos servidores públicos. Segundo ele, essas concepções tem contribuído para que as greves no âmbito do serviço público se realizem sem qualquer controle jurídico, dando ensejo a ausências que comprometem a própria prestação do serviço público, sem qualquer base legal ${ }^{98}$.

O medo do direito de greve também se reflete na afirmação do ministro Gilmar Mendes de que os servidores, ao fazerem greve sem nenhum controle judicial, tornam-se entidades soberanas, o que, segundo ele, é absolutamente inaceitável em um Estado de Direito ${ }^{99}$.

Esse sentimento também pode ser percebido na própria história do direito de greve no Brasil. Como ressalta Raimundo Simão de Melo, a liberdade sindical somente foi conquistada, embora relativamente, com a Constituição de 1988, que também concedeu o direito de greve aos trabalhadores. Até então, a greve era praticamente proibida, pois era considerada como delito e prática antissocial $^{100}$.

\footnotetext{
${ }^{97}$ DERRIDA, Jaques. Força de Lei. Tradução de Leyla Perrone-Moisés. São Paulo: Martins Fontes, 2010, p. 77-78.

${ }^{98}$ BRASIL. STF. MI 712-8. Relator: Min. Eros Grau. DJe 31.out.2008, p. 47.

${ }^{99}$ BRASIL. STF. MI 712-8. Relator: Min. Eros Grau. DJe 31.out.2008, p. 111.

${ }^{100}$ MELO, Raimundo Simão. A Greve no Direito Brasileiro. 3. ed. São Paulo: LTr, 2011, p. 39.
} 
Como afirma Cristiano P. Araújo Pinto, no Brasil, desde os primeiros movimentos operários, a greve é vista como caso de polícia. No Estado Novo, fazer paralisação era crime e o tipo penal continuou a valer, conforme decidiu o STF na década de 1950, mesmo após à ditadura de Vargas. No regime militar, era comum dizer que vigorava a lei "anti-greve", devido às muitas exigências para a deflagração de um movimento paredista.

Conforme Araújo Pinto, mesmo no período posterior à Constituição de 1988, no qual estamos, pode-se dizer que está apenas no início o aprendizado da sociedade em relação aos movimentos grevistas. Segundo ele, "é ainda muito comum encontrar decisões judiciais que praticamente anulam o exercício desse direito, ao impor a manutenção de serviços que podem chegar a 70 a $80 \%$ da força de trabalho ou deferir aos empregadores interditos proibitórios para afastar os trabalhadores das portas das fábricas, agências bancárias e estabelecimentos comerciais" ${ }^{101}$.

Desse modo, o que o Estado teme, em sua força maior, não é o crime ou banditismo, mesmo em grande escala, o que o Estado teme é a violência fundadora, capaz de justificar, legitimar ou transformar as relações de direito e, portanto, de se apresentar como direito ao direito. Segundo Derrida, "essa violência pertence, assim, de antemão, à ordem de um direito de transformar ou de fundar, mesmo que ela possa ferir nosso sentimento de justiça" ${ }^{102}$.

O direito de greve é, portanto, a violência como exercício do direito e o direito como exercício da violência. Esse direito deve ser exercido contra o Estado e contra a sociedade, mesmo que a maioria se sinta incomodada ou injustiçada.

A decisão proferida no $\mathrm{Ml}$ № 712 nos permite também analisar o papel do STF em relação ao sistema jurídico e à sociedade brasileira. Nesse sentido, a cientista política Ingeborg Maus examinou a tradição da jurisprudência constitucional alemã à luz de conceitos psicanalíticos e chegou a importantes conclusões sobre a expansão do controle normativo protagonizado pelo Poder Judiciário. Muitas dessas críticas podem ser aplicadas ao Judiciário e à Corte Constitucional brasileira, particularmente, em razão da influência do modelo constitucional alemão,

101 ARAÚJO PINTO, Cristiano O. P. A. Greve e Democracia. UnB Agência. Disponível em: http://www.unb.br/noticias/unbagencia/artigo.php?id=307. Acesso em: 13/11/2011.

${ }^{102}$ MELO, Raimundo Simão. A Greve no Direito Brasileiro. 3. ed. São Paulo: LTr, 2011, p. 81-82. 
principalmente, no que diz respeito ao sistema decisório, marcado pelas ideias e modelos apresentados por Robert Alexy e pela axiologia jurídica.

Segundo Ingeborg Maus, "por trás de generosas ideias de garantia judicial de liberdades e da principiologia da interpretação constitucional podem esconder-se a vontade de domínio, a irracionalidade e o arbítrio cerceador da autonomia dos indivíduos e da soberania popular, constituindo-se como obstáculo a uma política constitucional libertadora" ${ }^{103}$.

Segundo a cientista política, o século $X X$ foi marcado não só pela ampliação objetiva das funções do Judiciário, com o aumento do poder da interpretação ou com a consolidação do controle jurisdicional sobre o legislador, mas por uma representação da Justiça por parte da população com contornos de veneração religiosa. Desse modo, o Judiciário passa a revelar-se na imagem do pai, o que é indicado, principalmente, pela vasta literatura a respeito da biografia de juízes, que aparecem como "profetas" ou "deuses do Olimpo do direito" ${ }^{104}$.

Isso indica, portanto, que os pressupostos para uma decisão justa e racional residem exatamente na formação da personalidade de juízes. Segundo Ingeborg Maus, os direitos fundamentais e seus intérpretes seriam o símbolo da unidade do povo alemão, após a queda da monarquia. Desse modo, é a "excepcional personalidade do jurista" que indica a existência de uma ordem de valores justa. Para ela, isso representa o clássico modelo de transferência do superego, que elimina as discussões e procedimentos do processo de construção política do consenso, que passa a ser alcançado por meio da centralização da "consciência" social na Justiça.

Isso significa, portanto, que a Corte Constitucional tem-se assumido como consciência de toda a sociedade, materializando-se em seu "tutor moral". O tribunal dispõe de um conceito de direito que é, então, o produto das suas ponderações morais. Segundo Ingeborg, o Tribunal Federal Constitucional da Alemanha frequentemente tem atuado como verdadeiro parlamento ou última instância da definição de todos os valores de uma sociedade:

\footnotetext{
${ }^{103}$ MAUS, Ingeborg. Judiciário como superego da sociedade: o papel da atividade jurisprudencial na sociedade órfã. Tradução: Martonio Lima e Paulo Albuquerque. Novos Estudos CEBRAP, n. 58, nov. 2000, p. 183.

${ }^{104}$ MAUS, op. cit., p. 185.
} 
Pode ocorrer que penetre nesse foro interno aquela instância que compreende a si própria como moral e que, de maneira tão incontroversa, é reconhecida como consciência de toda a sociedade, de tal modo que a imagem paterna à qual se resiste atue concomitantemente como ponto de partida do clássico modelo da transferência do superego e como representante de mecanismos de integração despersonalizados. A pergunta a ser feita é, portanto, a seguinte: não será a Justiça em sua atual conformação, além de substituta do imperador, o próprio monarca constituído? ${ }^{105}$

Nesse sentido, é possível questionar se o Supremo Tribunal Federal, ao decidir questões jurídicas a partir do método da ponderação, que apresenta uma gradação de princípios constitucionais, ou mesmo, a partir de julgamentos de valor, que apresentam resultados no sentido do que é melhor ou pior, bom ou ruim para a sociedade, não estaria, assim como o Tribunal Federal Constitucional alemão, apresentando-se como tutor moral da sociedade. Além de discutir valores morais que deveriam ser definidos e discutidos pelo processo político de construção do consenso, que é, originariamente, atribuído ao Poder Legislativo, o STF pretende aplicar suas decisões a toda a coletividade, atribuindo a elas eficácia erga omnes. Ora, quando o judiciário extrapola os limites do caso concreto ele atua, sim, no sentido de tutelar moralmente a coletividade.

Segundo Ingeborg Maus, a partir dessa perspectiva de atuação, o próprio Tribunal Federal Constitucional alemão passou a discutir sua própria competência e métodos de interpretação, menosprezando qualquer limitação constitucional. O tribunal afirmou que seus parâmetros para o controle de constitucionalidade das leis não deveriam ser pautados pela Constituição vigente, podendo extrapolar seus horizontes. Tal competência deriva, então, de princípios de direito suprapositivos que o próprio tribunal desenvolveu em sua atividade constitucional de controle normativo ${ }^{106}$.

Desse modo, o TFC alemão submete as demais instâncias políticas à Constituição por ele interpretada, mas exime-se de qualquer vinculação às normas constitucionais. O tribunal revela-se, dessa forma, como autoritário, disfarçando seu decisionismo submetendo litígios sociais a uma Constituição "corretamente interpretada":

\footnotetext{
${ }^{105}$ MAUS, op. cit., p. 187.

${ }^{106}$ MAUS, op. cit., p. 191.
} 
Por conta dos seus métodos específicos de interpretação constitucional, atua o TFC menos como "Guardião da Constituição" do que como garantidor da própria história jurisprudencial, à qual se refere legitimamente de modo auto-referencial. Tal história fornece-lhe fundamentações que não necessitam mais ser justificadas, sendo somente descritas retrospectivamente dentro de cada sistema de referências ${ }^{107}$.

Não é possível deixar de estabelecer paralelos entre a postura do TFC alemão e o Supremo Tribunal Federal que, por diversas vezes, tem atuação semelhante. A Corte Constitucional brasileira também atua no sentido de, ela própria, definir sua competência, como ocorre no caso em análise, que apresenta uma redefinição da competência do tribunal em torno do mandado de injunção. As auto-referências em relação a própria jurisprudência também são constantes e utilizadas como argumentos de autoridade, basta a referência a uma jurisprudência do tribunal para que o argumento já esteja justificado.

Segundo Ingeborg Maus, quando a jurisprudência trata seus próprios pontos de vista morais como regras jurídicas, qualquer fato imaginável pode ser identificado como juridicamente relevante e transformado em matéria de decisão judicial. Desse modo, a apropriação desses espaços jurídicos por uma Justiça que tem convenções morais como fundamento revela a presença da coerção estatal, "que na sociedade marcada pela delegação do superego se localiza na administração judicial da moral" ${ }^{108}$.

A análise apresentada por Ingeborg Maus nos permite, portanto, refletir quanto ao verdadeiro papel do STF, principalmente, em relação àquilo que não está explícito em sua atuação. A atividade de controle normativo judicial, como apresentada no atual modelo de Estado constitucional, que revela a Corte Suprema como última instância de definição de valores da sociedade, o que contribui para a perda da racionalidade jurídica ou mesmo para racionalizações autoritárias, as quais, como afirma Ingeborg Maus, são tanto mais danosas porque inconscientes.

A análise desenvolvida em torno do Mandado de Injunção no 712 revela a necessidade de repensarmos nossos modelos e conceitos, principalmente no que diz respeito à atuação e ao modelo decisório do Supremo Tribunal Federal.

\footnotetext{
${ }^{107}$ MAUS, op. cit., p. 192.

${ }^{108}$ MAUS, op. cit., p. 201-202.
} 
É preciso destacar, contudo, que a decisão proferida no MI no 712, para além de revelar uma leitura axiológica da Constituição, foi capaz de apresentar uma virada de jurisprudência em torno do mandado de injunção, o que se revelou uma mudança positiva para o sistema jurídico brasileiro, apesar de ter se realizado por fundamentos questionáveis. A decisão proferida foi capaz de tematizar o direito de greve dos servidores públicos que, por muitos anos, encontrava-se relegado à condição de ilegalidade. A discussão sobre o tema permitiu o aumento de complexidade em relação ao direito de greve, que agora é exercido por diversas categorias de servidores públicos. 


\section{CONSIDERAÇÕES FinaIS}

Para compreender a forma e os fundamentos pelos quais o STF julgou - $\mathrm{Ml} \mathrm{n}^{-}$712, investigamos as correntes filosóficas da axiologia e deontologia jurídicas, que se revelaram em teorias sobre a compreensão da Constituição e sobre diferentes métodos de decisão judicial.

A axiologia jurídica é uma corrente filosófica que identifica o discurso jurídico com o discurso moral. Segundo Alexy, princípios podem ser compreendidos como valores e vice-versa. Dai decorre a compreensão de que princípios são passíveis de colisão, cuja solução se dará pela ponderação entre eles. Dizer que princípios são ponderáveis significa dizer que eles serão efetivados apenas na medida do possível, e que são sacrificáveis entre si, já que são "mandatos de otimização".

Para a axiologia, o juiz é o participante e a chave do discurso do direito, ao qual cumpre deliberar sobre a incidência, gradação e eficácia de um princípio. Cabe ao juiz, portanto, decidir o que é justo e em que grau é justo. A decisão proferida é valorativa e será legítima à medida que o juiz aplicar o método, o qual "garantirá a racionalidade" das decisões. O problema é que a axiologia apresenta um sistema decisório que permite ao juiz atuar como legislador e como tutor moral da sociedade, valorando a própria Constituição, esvaziando seu poder normativo e corrompendo o seu papel democrático.

A deontologia jurídica, por sua vez, compreende o direito em sua integridade, o que significa que as normas públicas devem ser consideradas como um sistema único e coerente de equidade e justiça. Segundo Dworkin, é a integridade a chave para se decidir casos jurídicos difíceis. Segundo essa perspectiva, princípios não são passíveis de colisão, eles apenas se tencionam, pois, no todo, são coerentes. Isso significa dizer que princípios não são ponderáveis ou sacrificáveis entre si. Sua precedência ou aplicabilidade deve ser aferida apenas para o caso concreto, diante de suas especificidades.

O direito como integridade exige, portanto, que os princípios e direitos fundamentais tenham o seu valor e a sua força normativa preservados assim como a Constituição determina. Operar um direito constitucional de forma deontológica 
significa excluir interpretações políticas majoritárias que visem prejudicar o exercício desse direito. Significa limitar a influência de pretensões outras que não sejam exclusivamente jurídicas, como dos campos da política, da moralidade ou da economia. Significa dizer que as decisões judiciais devem ser tomadas com fundamentos de princípio e não de política.

O direito de greve, por sua vez, revelou-se como direito à violência, a qual, segundo Derrida, é a violência fundadora do direito, capaz de justificar, legitimar ou transformar as relações jurídicas. A greve é aquilo que suspende o direito e que pretende contestar a própria ordem existente, criando uma situação revolucionária, para a fundação de um novo direito.

Ao julgar o MI no 712, o STF continuou a entender o direito de greve dos servidores públicos como de eficácia limitada, o que revelou a ausência de uma leitura deontológica da Constituição, já que a mesma prevê a aplicabilidade imediata dos princípios e normas definidoras de direitos fundamentais. A expressão "nos termos e limites da lei" inscrita no art. 37, VII, deve ser interpretada como possibilidade de posterior regulamentação pelo legislador infraconstitucional, não no sentido de condicionar o exercício de uma garantia constitucional à edição de tal norma.

Segundo o Min. Eros Grau, o art. 37, VII, que prevê o direito de greve dos servidores públicos, consiste em uma norma especial em relação ao caráter geral veiculado pelo art. 9. Para justificar tal afirmação, o ministro se utilizou de argumentos de política, que visam promover uma concepção de bem-estar geral e que são, em essência, argumentos valorativos, adequados ao processo de decisão política. Segundo Eros Grau, a greve no serviço público se choca ao interesse social e sua continuidade deve ser assegurada em benefício de toda a comunidade. Além de se adequar à axiologia jurídica, concepção do ministro nega a própria essência do direito de greve, que é o direito de incomodar.

Segundo o Min. Gilmar Mendes, no caso, afigurou-se o conflito entre o direito de greve dos servidores e o direito a serviços públicos adequados e contínuos. O ministro tratou o caso a partir da perspectiva da ponderação defendida por Robert Alexy, que permite ao juiz decidir o grau de incidência e de eficácia de um princípio. O STF, ao valorar, não define o que é correto conforme a Constituição, mas o que é melhor para sociedade. Trata-se de uma abordagem axiológica da questão. 
Com o objetivo de dar eficácia ao direito de greve dos servidores públicos e às próprias decisões do tribunal, o STF reformulou o mandado de injunção. Segundo o Min. Eros Grau, constitui poder-dever do STF elaborar a norma supletiva faltante em casos de omissão do legislador, a qual deverá ser dada eficácia erga omnes para a solução de casos análogos.

Essa nova leitura do mandado de injunção é importante para que a Constituição seja conformada em sua força normativa. O mandado de injunção foi concebido com a função de garantir efetividade a direitos fundamentais cuja ausência de norma regulamentadora inviabilize seu exercício. No entanto, devemos questionar os fundamentos que motivaram a mudança de jurisprudência. Entendemos como correta a competência do Poder Judiciário para formular normas supletivas, em sua função normativa, porém, os efeitos dessa decisão não devem extrapolar os limites do caso concreto.

A decisão apresentada pelo STF tem fundamentos na axiologia jurídica, já que, assim como na ponderação, pretende encontrar soluções para além das especificidades do caso concreto, a serem aplicadas a casos futuros. Porém, admitir que o STF possa formular decisões que tenham caráter geral e abstrato, significa permitir que esse tribunal atue como legislador, intrometendo-se de forma indevida na esfera de competência do Poder Legislativo.

A solução delineada para o caso, portanto, não revela o direito de greve dos servidores públicos em sua essência. O raciocínio alexyano em torno do direito de greve retira do exercício desse direito sua natureza deontológica e o transforma num jogo de opinião pública. O STF trata o direito de greve dos servidores públicos como direito limitado, como problema valorativo, político e social. Isso ocorre também em razão do direito de greve se apresentar como uma ameaça à ordem jurídica, que é interna ao próprio direito. A forma como o STF compreendeu o direito de greve revela esse temor, esse medo que o Estado tem da violência que é capaz de ameaçá-lo ou, até mesmo, de destruí-lo.

A partir do MI oㅜ 712, também foi possível analisar o papel do STF em relação ao sistema jurídico e à sociedade brasileira. Ingeborg Maus analisou a tradição constitucional alemã e apresentou importantes críticas sobre a expansão do controle normativo do Judiciário, muitas as quais podem ser aplicadas ao STF em razão da influência do modelo constitucional alemão. 
Segundo Ingeborg, o Judiciário passa a revelar-se na imagem do pai, o que é indicado pela vasta literatura a respeito da biografia de juízes. Desse modo, é a "excepcional personalidade do jurista" que passa a indicar a existência de uma ordem de valores justa. Para ela, isso representa o clássico modelo de transferência do superego, que elimina as discussões e procedimentos do processo de construção política do consenso. Isso significa, portanto, que a Corte Constitucional tem-se assumido como consciência de toda a sociedade, materializando-se em seu "tutor moral".

Também segundo Ingeborg Maus, o Judiciário tem discutido sua própria competência, submetendo as demais instâncias políticas à Constituição por ele interpretada e menosprezando qualquer limitação constitucional. O STF, por diversas vezes, tem atuação semelhante. Desse modo, a Corte Suprema se revela como última instância de definição de valores da sociedade, o que contribui para a perda da racionalidade jurídica ou mesmo para racionalizações autoritárias.

É preciso, portanto, repensarmos nossos modelos e conceitos, principalmente no que diz respeito à atuação e ao modelo decisório do Supremo Tribunal Federal. Como visto, a Corte Constitucional apresentou uma mudança de jurisprudência em torno da conformação do mandado de injunção, o que, em si, revela a Constituição em sua força normativa, já que permite a tal instrumento realizar sua função, como constitucionalmente previsto. Os fundamentos que guiaram tal mudança de jurisprudência, porém, são problemáticos. A decisão proferida no MI no 712 não é capaz de revelar a assunção efetiva de uma leitura deontológica da Constituição.

O STF mudou a compreensão em relação ao mandado de injunção numa forte convergência para uma leitura axiológica do direito. A nova feição atribuída ao remédio constitucional apresentou uma aplicação valorativa da Constituição no que tange ao direito de greve dos servidores públicos. A mudança de jurisprudência também se dá em razão de uma leitura de temor, de reação do aplicador do direito à greve.

Contudo, é importante perceber que decisão proferida foi capaz de tematizar o direito de greve dos servidores públicos que, por muitos anos, encontrava-se relegado à condição de ilegalidade. A discussão sobre o tema permitiu o aumento de complexidade em relação ao direito de greve, que agora é exercido por diversas categorias de servidores públicos. 
Da análise e do estudo desenvolvidos também se deve ressaltar que o que é realmente importante no debate sobre o direito não é apenas o sentido da Constituição, das decisões judiciais ou das normas jurídicas, mas o próprio conceito de direito. A análise nos leva, portanto, ao conceito que os ministros do STF possuem do direito e suas principais consequências. 


\section{REFERÊNCIAS}

ALEXY, Robert. Direitos Fundamentais, Balanceamento e Racionalidade. Tradução de Menelick de Carvalho Neto. Ratio Juris, v. 16, n. 2, p. 131-40, jun. 2003.

El Concepto y la Validez del Derecho. Tradução de Jorge M. Seña. $2^{\underline{a}}$ ed. Barcelona: Editoria Gedisa, 2004.

Teoria da argumentação jurídica. Tradução de Zilda Hutchinson Schild Silva. São Paulo: Landy Editora, 2001.

ARAÚJO PINTO, Cristiano O. P. A. Greve e Democracia. UnB Agência. Disponível em: http://www.unb.br/noticias/unbagencia/artigo.php?id=307. Acesso em: 13/11/2011.

ARAÚJO PINTO, Cristiano O. P. A.; LOURENÇO FILHO, Ricardo. A greve e sua conformação pelo TST: Desvelando Mentalidades. In: O mundo do trabalho, volume I: leituras críticas da jurisprudência do TST: em defesa do direito do trabalho. São Paulo: LTr, 2009, p. 65-76.

ATIENZA, Manuel. Entrevista a Robert Alexy. Doxa, Cuadernos de filosofia Del derecho. Alicante, n. 24, 2001, p. 671-687.

BARBOSA, Leonardo. Colisão de direitos fundamentais sob a perspectiva da teoria da argumentação jurídica: um diálogo entre Robert Alexy, Klaus Günther e Jürgen Habermas. Brasília, 2003. Documento não publicado.

BRASIL. Constituição (1988). Constituição da República Federativa do Brasil: promulgada em 5 de outubro de 1988. Disponível em: http://www.planalto.gov.br/ccivil 03/constituicao. Acesso em: 13/11/2011.

BRASIL. Lei 7.783 (1990). Dispõe sobre o exercício do direito de greve, define as atividades essenciais, e dá outras providências. Congresso Nacional. Disponível em: http://www.planalto.gov.br/ccivil 03/leis/L7783.htm. Acesso em: 13/11/2011.

BRASIL. STF. Mandado de Injunção 712-8. Relator Ministro Eros Grau. Acórdão publicado no Diário de Justiça Eletrônico de 31.out.2008. 
DERRIDA, Jaques. Força de Lei. Tradução de Leyla Perrone-Moisés. São Paulo: Martins Fontes, 2010.

DWORKIN, Ronald. Levando os direitos à sério. Tradução de Nelson Boeira. São Paulo: Martins Fontes, 2002.

. O império do direito. Tradução de Jefferson Luiz Camargo. São Paulo: Martins Fontes, 2007.

Uma questão de princípio. Tradução de Luís Carlos Borges. São Paulo: Martins Fontes, 2001.

MAUS, Ingeborg. Judiciário como superego da sociedade: o papel da atividade jurisprudencial na sociedade órfã. Tradução: Martonio Lima e Paulo Albuquerque. Novos Estudos CEBRAP, n. 58, p. 183-202, nov. 2000.

MELO, Raimundo Simão. A Greve no Direito Brasileiro. 3. ed. São Paulo: LTr, 2011.

\section{DOCUMENTOS CONSULTADOS}

EBERT, Paulo Roberto Lemgruber. O direito de greve dos servidores públicos após julgamento dos mandados de injunção no 670, 708 e 712 pelo Supremo Tribunal Federal. In: Revista IOB: trabalhista e previdenciária, v.20, n.231, p.83100, set., 2008.

LIMA, Francisco Gérson Marques de. Direito de greve no serviço público. In: O Supremo Tribunal Federal na crise institucional brasileira: estudos de casos: abordagem interdisciplinar de sociologia constitucional. São Paulo: Malheiros, 2009. p. 582-594.

LIMA, Juliana Maggi. O direito de greve dos servidores públicos e o STF. In: Jurisprudência constitucional: como decide o STF? São Paulo: Malheiros, 2009. p. 483-499. 
MENDES, Gilmar Ferreira; COELHO, Inocêncio Mártires; BRANCO, Paulo Gustavo Gonet. Curso de Direito Constitucional. São Paulo: Saraiva, 2009.

PORTO, Noemia Aparecida Garcia. A greve como direito: irritações entre os sistemas e desafios à estabilização de experiências. In: Revista trabalhista: direito e processo, v.7, n.26, p.75-89, abr./jun., 2008. 